\title{
Equal Partners in Dialogue? Participation Equality in a Transnational Deliberative Poll (Europolis)
}

\author{
Marlène Gerber, Institute of Political Science, University of Bern
}

Accepted version of the manuscript (9 September 2014)

\begin{abstract}
By gathering a representative sample of citizens from all 27 EU Member States, the deliberative poll Europolis created the opportunity for the inclusion of a wide variety of European voices. Taking up claims of difference democrats who argue that informal hurdles to participation can endure even after individuals gain formal access to the floor, this article argues for an extended approach to evaluate equality in deliberative minipublics. Specifically, it assesses whether participants contributed in roughly equal measures to the discussion and whether their discussion partners considered their contributions on equal merits. In doing so, the article adds to the small but growing literature on deliberation that expresses reservations about taking the willingness to engage with others' claims for granted. In order to account for the intrinsically relational aspect of interpersonal communication, measures of social network analysis are introduced as possible tools to evaluate participation equality in deliberative encounters.
\end{abstract}

Keywords: deliberative polling; equal participation; European public; working class; social network analysis 
Recent years have witnessed a strong surge in existing mini-publics. The aim of such artificially created forums for small-scale public deliberation is to create 'more perfect public spheres' (Fung, 2003, p. 338), or 'safe havens, that are insulated from certain negative or distorting effects' (Chambers, 2004, p. 400). In this regard, mini-publics are often thought of as educative forums that allow room for a variety of views and perspectives to be expressed and seriously considered (Fung, 2003). Among these attempts, the deliberative poll (DP) developed by James Fishkin (1995) represents the gold standard in many respects, among other things in terms of representativeness (Mansbridge, 2010). By means of random sampling, DP attempts to create equal chances for everyone to be selected and to influence the decision process (Fishkin and Lustkin, 2005). Up to now, evaluations of political equality in DP have largely focused on the questions of whether the sample of deliberators was representative of a broader public (e.g. Andersen and Hansen, 2007; Luskin et al., 2002) and whether post-deliberative opinions were dominated by the view of a particular social group (e.g., Fishkin et al., 2010; Luskin et al., 2013).

Less is known, however, about the degree to which participants actually gained equal standing in the process of deliberation itself (see Hansen, 2010; Siu, 2009 for exceptions). This is a substantial shortcoming for at least two reasons. First, while offering everyone equal possibilities to participate in mini-public events is essential, it is in itself not a sufficient condition to establish equal participation (e.g., Cohen, 1989; Fraser, 1992; Young, 2002). Critics argue that informal hurdles to participation can persist even after individuals gain formal access to the floor. However, organizers of mini-publics such as the DP mitigate this concern by emphasizing that mini-public designs incorporate many procedural safeguards: the introduction of trained facilitators and specific rules for discussion should ensure that deliberation proceeds in a fair and equal way (e.g., Fishkin and Luskin, 2005). Yet, it is surprising how little the role of the facilitators has been theorized in the framework of deliberation, given the essential part that is attributed to facilitators in establishing an 
inclusive atmosphere for discussion (Smith, 2009, pp. 162-193; see Moore, 2012 for an exception). It comes as no surprise that the lack of theorization echoes in largely mixed results on facilitators' behavior and their potential influence on establishing a balanced atmosphere for discussion (e.g., Ryfe, 2006; Schneiderhan and Khan, 2008; Stromer-Galley, 2007; but see Trénel, 2010). Thus, an evaluation of deliberative participation that only focuses on formal access to deliberation may be insufficient. Second, estimating whether post-deliberative opinions are strongly influenced by a particular social group may not give a full account of whether participants were substantively equal in deliberation. Of course, confirming that disadvantaged groups were not forced to conform to the views of a dominant group by underlying power structures is a positive sign of deliberative inclusion. Yet, an outcomeoriented approach to participation equality might be too quick in assuming that serious reflection of others' arguments automatically manifests in opinion shift (Dobson, 2012, p. 844; see Barabas, 2004). In other words, whether others' thoughts manage to change one's opinion is, ideally, more a question of the force of the better argument than of the actual willingness to seriously consider others' claims in the light of one's own (Mansbridge, 1999, p. 225).

This article adds another layer to the literature on inclusiveness of deliberative mini-publics by analyzing participation equality in the process of deliberation itself. Specifically, the article argues in favor of two additional dimensions of substantive participation equality that are regarded as crucial preconditions to creating more informed and considered opinions. I dub them equal contribution and equal consideration. From such a perspective, I address the questions of the extent to which individuals participated at equal levels and whether their arguments were considered on equal merits. I propose multilevel modeling and social network analysis as possible methodological tools to address these questions. A subsample of small group discussions on third country migration that have been conducted in the framework of a pan-European deliberative poll (Europolis) serves as an empirical example. 
The remainder of the article is organized as follows. The next section contains the theoretical discussion on equal opportunities to influence the deliberative process and embeds the argument in deliberative theory. The third section presents the case study, details the statistical methodologies at use and displays information on the choice of variables. Subsequently, I present the main results and discuss the implications of the findings. The last section concludes and offers suggestions for future research.

\section{Participation Equality in the Deliberative Process}

From an epistemic point of view, deliberation is desirable because it holds the potential for incorporating a wide array of different perspectives (e.g., Bohman, 2006; Estlund, 1997; Mansbridge et al., 2012). By gathering a random sample of a given population, DP possesses the potential to expose participants to a wide range of facts and moral positions which may render individuals more considerate, further tolerance and may even reduce prejudice (Mutz, 2006). Although random sampling methods as utilized in DP may succeed in gathering a representative sample of a broader public and therefore fulfill a necessary condition for equal participation, they are in themselves not sufficient. ${ }^{1}$ Cohen (1989, pp. 22-23) states that not only do individuals need to be formally empowered to participate in deliberation, they also need to be substantively equal 'in that the existing distribution of power and resources does not shape their chances to contribute to deliberation, nor does that contribution play an authoritative role in their deliberation' (see also Young 2002). In this sense, 'deliberation depends on achieving an important kind of equality, equality as a partner in a dialogue' (Warren 2001, p. 81). Only a focus on the process of deliberation allows for testing whether this kind of equality has been reached.

During deliberation itself, equality could potentially be violated in two consecutive dimensions. First, some participants might not express themselves at appropriate length 
compared to some of their co-discussants which could result in domination of some perspectives over others or even worse, in non-communication of a particular perspective (Sanders, 1997; Young, 2002). Second, a speaker's opportunity to influence the political process is determined not only by the action of the speaker herself but also by the listeners' willingness to take the speaker's claim into account (Knight and Johnson, 1997; see also Bohman, 1997).

Note that Bohman makes an important distinction between being able to influence the process of deliberation and the ability to influence the outcome of deliberation (or, the ability to effectively influence the deliberative process) (see also Estlund, 2000). While the former requires active communication of one's central claims and others' willingness to weigh the merits of each claim on equal grounds, the latter additionally requires one's ability to convince others by superiority of reasoning. The scope of this article is limited to the former.

The following two subsections will elaborate on the two dimensions of equality that are of relevance during the process of deliberation. In the following, I refer to them as equal contribution and equal consideration.

\section{Equal Contribution}

Sure, the deliberative ideal of equal participation does not demand that everyone participates with equal numbers of words (Mansbridge, 1999, p. 232). However, equal participation requires that no person or particular group completely dominates the discussion, even though deliberators may differ in power and prestige (Thompson, 2008, p. 501). Patterns of dominance in discussion would have consequential framing and agenda-setting effects and preclude people from basing their judgments on the entire pool of relevant reasons (see e.g., Mendelberg, 2002).

Several scholars express reservations when it comes to the practicability of equal contribution (e.g., Benhabib, 1996; Sanders, 1997; Young, 2000). This is based on the fact that these 
critics attribute a calm and dispassionate style of expression to middle- and upper-class white men, while they view the emotive and physically demonstrative modes of expression to be strongly associated with women and cultural minorities. As a consequence, Young (2002) fears that historically oppressed segments of the population do not dare to speak, as they do not consider themselves able to fulfill the requirement of rational discourse (see Mansbridge, 1983). Yet some researchers would contest the concerns related to gender by arguing that women are particularly prone to deliberation, in that they pursue a kinder and gentler style of politics (Childs, 2004; Norris, 1996). Moreover, Neblo et al. (2010) provide convincing evidence that groups that normally display reluctance towards traditional means of political participation are actually more willing to participate in deliberation. Hoping to get a better hearing of their claims, these groups might view deliberation as a valuable alternative to 'politics as usual'. Whether mini-publics manage to activate disadvantaged groups to a substantial degree is still an open question and the few studies that addressed this subject so far in the context of DP provide mixed evidence. Concerning face-to-face-deliberation, Hansen (2010) detects equality biases for gender, education and age in discussions on the single European currency as conducted in the 2000 Danish DP. Similar results are obtained from another deliberative face-to-face encounter on building an additional nuclear power plant in Finland (Himmelroos, 2011). On the other hand, results from online Deliberative Polls on the 2004 Presidential nomination campaigns and the 2005 online Poll on health care and education did not detect such biases (Siu, 2009). So far, these results are in line with Price (2009, p. 43), arguing that more anonymous deliberative settings may reduce patterns of social dominance.

\section{Equal Consideration}

By filtering incoming information in a biased way, deliberators may infringe another form of equality. For deliberation to reach its full epistemic potential, post-deliberative preferences 
and decisions need to be based on facts and logic and be the outcome of 'substantive and meaningful consideration of relevant reasons' (Mansbridge et al., 2012, p. 11). In order for relevant reasons to enter the opinion formation process, deliberators' claims need to be listened to seriously (Bickford, 1996; Dobson, 2010). However, deliberative researchers often ignore the importance of listening in that they often (and against all evidence) assume that incoming information is processed in a uniform way (Dobson, 2012; Lupia, 2002; Mendelberg, 2002). From a viewpoint of equal opportunities to influence the deliberative process, however, it is essential that everyone be recognized as equal discussant with legitimate claims (e.g., Bohman, 1997; Knight and Johnson, 1997). Moreover, a demanding understanding of equal consideration requires recognition to go beyond the mere and rather passive act of listening to what others have to say. As Bickford (1996, pp. 153-159) succinctly puts it, silence may either be an indicator of attentive listening or a non-verbal refusal to engage with what others have said. In other words, deliberation requires uptake of and engagement with others' claims, so that people respond to claims 'as issues - that is, as matters that deserve response in their own terms' (Warren 2001, p. 81; see also Goodin, 2000, Knight and Johnson, 1997; Pedrini et al., 2013). The very interactive moment of reciprocal recognition is also embodied in Gutmann and Thompson's (1996, p. 79) definition of mutual respect, which demands a 'favorable attitude toward, and constructive interaction with, the persons with whom one disagrees'. According to the authors, a listener's willingness to treat a speaker with respect also demonstrates his commitment for self-reflection and openness to preference change. And it is only to the extent that the listener actively responds to what a speaker has said that everyone, including the speaker, is able to reflect on public deliberation (see Christiano, 2008, p. 201).

Again, critics question the direct applicability of such a deliberative ideal to real-world deliberation. One argument is that dominant groups may, even unconsciously, treat claims of people from traditionally disadvantaged groups with inadequate respect (Sanders, 1997; 
Young, 2002). If true, this would dispel many of the benefits accredited to deliberation: 'when this happens, democratic theory doesn't have an answer, because one cannot counter a pernicious group dynamic with a good reason' (Sanders, 1997, p. 354). Adequate consideration of others' views may also be more difficult to achieve when the group increases in heterogeneity. By bringing together people with different cultural backgrounds, more time and energy might be required in order to appropriately consider the full variety of speaking and reasoning styles (Benhabib, 2002; Burkhalter, 2002). The well-known insights provided by the interracial town meetings on school desegregation amplify some of these concerns (Mendelberg and Oleske, 2000). On the other hand, more optimistic conclusions are drawn when it comes to the uptake of claims from language minorities' in the Swiss parliament (Pedrini et al., 2013). Beyond these valuable insights, we lack empirical observations on the practicability of equal consideration. This is also true for DP, although Fishkin (2009, p. 160) admits that the degree to which equal consideration is realized cannot be prescribed by institutional design. In the transnational environment of Europolis, the viability of equal consideration may particularly be endangered by the fact that people enter the discussion with a variety of cultural backgrounds and experiences in the field of EU-politics and the topic of immigration (e.g., Geddes, 2003).

\section{Data and Measurement}

\section{Case Study (Europolis)}

I assess the degree of participation equality in the deliberative process on the basis of face-toface small group discussions on third country immigration to the EU, as conducted in a transnational deliberative poll (Europolis) which took place in Brussels in May 2009. By gathering a representative sample of the European population for deliberation, Europolis created a favorable environment for EU-citizens of all 27 member states to become 
substantially more informed about politics (Fishkin, 2009, pp. 159-195). Following standard practice of DP, Europolis incorporated pre- and post-questionnaires, the provision of balanced briefing material in the forefront of the event, as well as the possibility to discuss important issues in a plenary with experts and politicians. During the three-day event, about 350 participants from all 27 EU-member states discussed in 25 small groups of 11 to 16 participants the topics of third country migration and climate change. The groups were created by random variations of the languages spoken, which resulted in including participants from two to five different nationalities per group. The small groups were moderated by trained facilitators whose task was to keep discussion open and balanced, and the speeches provided were simultaneously translated in all languages spoken in the group. Due to limitations in simultaneous translation, national heterogeneity of Europolis small group compositions varied to a considerable degree: while some groups encompassed a wide variety of nationalities, in others it merely came down to a discussion among neighbors. Therefore, the Europolis project presents an interesting case for analyzing small group deliberation with varying degrees of European diversity.

For demonstrating purposes, I refrained from analyzing all 25 small group discussions. Rather, I took a subsample of 13 groups and limited the analysis to the general discussion on immigration and the more specific discussion on policy options that address third country migration. Although the selected subsample is limited in scope with regard to EU member states, it is comparable to the rest of the sample with regard to important socio-demographic and motivational variables. Despite its limitations concerning the representation of different nationalities, the sample consists of groups that show notable variation in national heterogeneity (see Appendix).

\section{Assessing Equality of Contribution}


Since there is no universal agreement on how to capture contribution, a double-track approach is pursued. A participant's contribution is captured via the amount of speaking time (in seconds) and the frequency of contribution (Bächtiger et al., 2010b). Linear multilevel models are estimated for the logarithm of speaking time since the distribution of speaking time is strongly skewed to the left and ranges from 0 to 1593 seconds (26.5 minutes) of speaking

time in a total of approximately 1.5 hours of discussion time. ${ }^{2}$ Random slopes instead of random intercept models are estimated since overall speaking time was roughly equal in all groups. The slopes for participants of EU-members that joined the EU in 2004 or later were allowed to vary. The underlying assumption is that members of new EU-countries show a more balanced participation behavior if they discuss only among themselves. The distribution of frequency is also strongly skewed to the left, ranging from 0 to a total of 21 delivered speeches. Here, Poisson models for count data were estimated. In order to account for overdispersion, Poisson lognormal models are estimated by adding an individual-level random effect to the models estimated with lme4 (Bates et al., 2011; Bolker, 2010).

\section{Assessing Equality of Consideration}

Consideration is based on the updated DQI indicator of respect towards other participants' arguments (Bächtiger et al., 2010b; see Steiner et al., 2004). The DQI indicator captures interactivity, or the uptake of arguments, in assessing whether speakers explicitly referred to others' arguments in a disrespectful, neutral or respectful manner or whether they ignored other participants' statements. Given the explanations above, I regard a view to be explicitly considered if someone directly addresses a previous speaker in response to something he had said. In a first step, interactive instances have been coded from the transcripts of the group discussions. An inter-coder reliability test by three independent coders showed respectable levels of agreement on the coding. ${ }^{3}$ By assessing the nature of the reference as well as the sender and the receiver of a reference, a matrix of argumentative uptake can be created 
(Pedrini et al., 2013). This presents the basis for further analysis. In this paper, I focus on explicitly neutral or positive references and subsume them under the category of "civil references'. I ignore disrespectful references, since they violate the fundamental notion of constructive interaction (Gutmann and Thompson, 1996; Mansbridge et al., 2012). ${ }^{4}$ Moreover, instances of disrespect were rare in Europolis. This is not surprising given that in DP, stakes are low and participants are encouraged to meet others with respect (Fung, 2003). In order to retrieve the measure for consideration, I rely on network measures. Since deliberation is a communicative act and an 'individual functions as a part of the group and each influences the other' (Mendelberg, 2005, p. 645), social network analysis may help to capture elements of deliberative inclusion. With a few exceptions, network structures of deliberative discussions remain largely unexplored (but see Cinalli and O'Flynn, 2013; Pedrini et al., 2013). For this purpose, an actor's centrality has been calculated from the matrix. Centrality measures capture an actor's connectedness to a set of other actors and are commonly viewed as an indicator of an actor's power within the network (Krackhardt 1990). In deliberative discussions, an actor's power may be determined by the degree to which his views have been taken up by his co-discussants. In order to evaluate whether participants' claims have received equal consideration, the dependent variable will be operationalized as a measure of consideration centrality. For this purpose, I focus on in-degree relations, i.e. the amount of references that a participant receives. Concretely, the network centrality measure encompasses the total number of co-discussants that made a civil reference to a speaker at least once. In the Europolis subsample, in-degree centrality ranges from 0 (a person spoke but has never been referenced) to 10 (a person was referenced by 10 different co-discussants at least once). ${ }^{5}$ Since the distribution is strongly skewed to the left, lognormal Poisson models are estimated (see above).

In order to explore consideration structures a bit further, network measures of homophily (McPherson et al., 2001) may be of particular relevance. An empirical approach to equal 
consideration not only requires that claims are taken up, but also that the claims of some groups have been considered by other groups (Pedrini et al., 2013). In this sense, homophily analysis may serve as an important complement to the analysis of consideration centrality. Homophily is defined as the tendency for similar individuals to form a relation (McPherson et al., 2001; see Lazer et al., 2011). Translated to the deliberative setting, homophily allows for testing whether members of a dominant group remained sufficiently open to claims raised by more peripheral actors or whether they preferred to engage with dominant others and thus contributed to the monopolization of the discussion.

\section{Predictor Variables}

In order to test whether different perspectives were appropriately aired and considered, I include the following variables of interest in the model that were captured by the predeliberative Europolis questionnaire (see Appendix for more detailed information on the operationalization):

In terms of socio-demographics, Hainmueller and Hiscox (2007) detect a general increase in immigrant support with higher educational and skill levels when analyzing data from the European Social Survey 2003 (ESS). Using data on the ESS conducted in 2004/05, Masso (2009) also identifies a general tendency for younger people towards openness to cultural diversity and thus readiness to accept immigrants (see also Hanmueller and Hiscox, 2007). Similarly, gender effects were located. However, they disappear when controls for values such as tolerance and the importance for traditions and cultures are introduced in the model (Hainmueller and Hiscox, 2007, p. 432) but this also nourishes the view of the caring and empathetic woman (Norris, 1996). For all these reasons, a binary variable for gender, taking in the value (1) for women and (0) for men; another binary variable indicating whether a person feels that she belongs to the working-class (1) or to the middle or upper class (0); a 
variable for education, measured in years of age when the education ended; and a categorical variable for age, classifying a person into being young (18-34 years old), intermediate (35-64 years old) or older (65 and above). The categorization of age was undertaken because previous findings suggest a non-linear effect for age, with the group of middle aged discussants being the most active (Hansen, 2010; Himmelroos, 2011).

In order to account for attitudinal diversity in positions towards immigration and potential policies, a categorical variable is introduced that tabs whether a person's attitude on immigration is conservative, progressive, or moderate. Originally, this variable has been built as a scale from five central questions on immigration as posed in the Europolis predeliberative questionnaire. They proved to be substantially related in a test of inter-item correlation $(\alpha=0.76)$. Subsequently and following the same logic as for age, the upper and the lower 25 percent quantile of the scale were classified as progressive and conservative, respectively. The 50 percent in-between were considered to hold moderate attitudes on the issue.

Two additional variables were introduced in order to account for the impact of national diversity. At the individual level, an additional categorical variable distinguishes between people belonging to a Western European (0), a Southern European (1) or a Central Eastern European state that joined the EU in 2004 or later (2). Of course, this presents an oversimplification in terms of existing diversities in national immigration policies as well as experiences with immigration (see Papadopoulus 2012). However, such a typology can be based on economic, geopolitical, historical and geographical considerations (see, e.g., Geddes, 2003, Hainmüller and Hiscox, 2007). ${ }^{6}$ At the group level, a measure was created to capture the degree of national heterogeneity that was present within the groups. The measure is based on a weighed version of the Ethno-Linguistic Fractionalization Index (ELF) (see Fearon and Laitin, 2003). ${ }^{7}$ The idea for introducing such a group level variable stems from 
literature on multiculturalism, arguing that deliberation among people with different cultural backgrounds needs more time to encompass a wide variety of experiences and perspectives (see above). This might particularly be true when deliberating on an issue that lies at the core of the nation state, such as immigration and incorporation (Benhabib 2002).

Additional individual level factors are introduced as controls. All of them are expected to enhance an individual's motivation and thus engagement in discussion (see, e.g., Neblo et al., 2010). These are: interest in politics, an indicator for salience that aims to capture the personal relevance of the topic and an indicator for knowledge on immigration. All variables are detailed in the Appendix. ${ }^{8}$

\section{Results}

In a first step, multilevel models for contribution were estimated. Model 1 in Table 1 presents the results of the lognormal Poisson models for frequency of participation. Belonging to a Central Eastern European (CEE) member state is supposed to reduce participation by $30 \%$ of the expected count. A strong reduction is also suggested for members of the working-class ($23 \%)$. However, there is still a considerable degree of statistical uncertainty in the latter two estimates $(\mathrm{p}<0.1)$. Yet, the picture looks somewhat different when focusing on speaking time, the second indicator of contribution equality (Model 2, Table 1). Exponentiating the estimate for women shows that the significant reduction in speaking time is considerable $(-48.5 \%)$, holding all other factors constant. Even higher is the estimated reduction in speaking time for participants from CEE states (-54.3\%), although the effect slightly misses the level of marginal significance $(\mathrm{p}<0.1)$. While working-class participants are biased when it comes to frequency of speaking, there is no significant evidence that this bias translates to the amount of speaking time. In both models, no bias is detected for age, education, gender and attitudes towards migration. When turning to the control variables, interest in politics is a clear driver 
of contribution, both in terms of utterances and total amount of speaking. Furthermore, knowledge excerts a significant and substantial effect on speaking time.

\section{[TABLE 1 ABOUT HERE]}

One fear of deliberative critics is that participation biases increase with the heterogeneity of the discussion environment (e.g., Karpowitz et al., 2009). Empirically, this is most pronounced for women and participants from new EU-member countries. ${ }^{9}$ Figure 1 displays the marginal effect of gender and CEE participants on contribution by varying degrees of national heterogeneity. The effects are based on the Models in Table 1 but incorporate an

additional cross-level interaction term. ${ }^{10}$ Again, the bias is more pronounced for the models of speaking time while the effect for frequency of contribution does not reach sufficient levels of statistical significance. In terms of speaking time, women's effect on contribution was significantly and substantially different from zero in the nine most heterogeneous discussion groups, while the gender gap is smaller and less certain in the more homogeneous groups. More worrisome is the picture for participants from new EU-member countries. The shaded area demarcates the location of the groups in which participants of the new CEE member states were engaging with participants from older EU-member states (Western, Southern, or both). From a perspective of European integration, the results are somewhat troubling: when engaging with participants from older EU-countries, the newcomers are very likely to add significantly less to the discussion.

\section{[FIGURE 1 ABOUT HERE]}

In the Danish deliberative poll, Hansen (2010) concludes that the gender gap is particularly pronounced among the least active participants. The findings are similar in Europolis: If we exclude participants from the model that did not speak at all $(\mathrm{N}=11)$ the effect size for women on contribution in terms of speaking time decreases substantially. The effect, however, remains significant. On the other hand, the effects for working-class participants increases 
both in magnitude and clarity (see Table 2). Among the ones who spoke, working-class participants seem to be the ones with the smallest amount of contribution. These results are important to keep in mind when turning to the consideration models, since actual contribution is a necessary precondition for receiving consideration.

\section{[TABLE 2 ABOUT HERE]}

Let us now turn to the determinants of consideration (Table 2, Model 5). In terms of biases for our marginalized groups, the consideration model seems to be somewhat a reflection of the frequency model for speakers presented in the same table (Model 4), indicating that the ones who spoke more often were also the ones whose views were considered more often by others. ${ }^{11}$ With a value of 0.73 , the bivariate correlation between consideration centrality and frequency of speaking is indeed considerable. According to the estimates, being a member of the working-class accounts for a 39\% decrease in receiving consideration. For women and new EU-members, results look more promising: while there are some inequalities in terms of contribution among participants of these groups, there is no concrete evidence for their marginalization in terms of consideration. On the other hand, more conservative attitudes on immigration received somewhat more consideration than one would have expected from their level of contribution. Such an effect does not exist for participants holding progressive attitudes.

Again, interaction models for gender and CEE participants were estimated. Figure 2 plots the marginal effects for gender and CEE members on receiving consideration. There is no concrete evidence that new EU-members received significantly less consideration than their older European peers. Yet, the confidence intervals for women in the most heterogeneous groups are different from 0 , suggesting that women receive significantly less consideration when they engage in highly heterogeneous groups. 
Previous results render slightly optimistic in suggesting that marginalized groups in terms of speaking nevertheless managed to gain themselves an ear - at least roughly to the degree they contributed to the discussion. In a next step, however, we may also want to know whether arguments of the more peripheral groups have been fairly considered by members of the dominant group (see Pedrini et al., 2013). Discovering that views of marginalized group members only found appropriate consideration among members of the peripheral groups would reveal the previous optimism as too hasty. Therefore, we turn to the question of homophily. Homophily analysis explores whether individuals' views were more likely to be considered by similar others. While the absence of homophily would suggest that the claims of peripheral groups reasonably entered the consideration process of members of the dominating groups, evidence of homophily might imply that exclusionary mechanisms were at work. I test for homophily by comparing network densities of the consideration networks between peripheral and dominant groups (see Lazer et al., 2010). Network densities are calculated as the total number of existing relations (here: references) over the total number of possible relations. Densities can take in any number between 0 (here: indicating that no one's view was referenced) and 1 (indicating that everyone's view was referred to by all members of the group). Figure 3 displays the percentage point differences in within- and between-group densities (for exact figures, see Appendix, Table A.5 to A.7). Positive numbers indicate a tendency for homophily (more references were made to in-group members), while numbers below zero indicate a tendency toward heterophily (more references were made to out-group members). While the triangles display the differences in densities for the more dominant cohorts (separately, for each small group discussion), the circles show the same from the perspective of the marginalized groups.

[FIGURE 3 ABOUT HERE] 
Figure 3 reveals an overall tendency toward homophily for men, non-working-class participants and citizens of older EU-countries: the dominating groups in terms of contribution tend to consider views from their peers more often than views of their more peripheral discussion partners. Yet the extent to which they do that varies greatly from group to group. For example, while in three groups, participants from older EU-countries were equally likely to interact with participants from CEE countries as with their peers, another group shows a 50 percentage point difference in favor of referencing their dominant peers. As an illustration, Figure 4 graphs the consideration network of the latter group.

\section{[FIGURE 4 ABOUT HERE]}

Turning to the marginalized groups (circles), the reverse picture is on display. In the large majority of the group discussions, women, working-class participants and members from new EU-countries showed higher consideration densities towards members of the dominant outgroup. Yet there are two notable exceptions for gender: in two comparatively homogeneous groups (group 3, WE members only; group 16, CEE members only), women received more references from both male and female participants.

Additional analyses show that in 8 out of 13 groups (11, respectively), women and workingclass participants received, in absolute terms more reference from the central actors than from members of the peripheral groups. Thus, the fact that marginalized groups received somewhat less consideration compared to their dominating counterparts is not necessarily due to a lack of interest from the side of the central groups. Rather, marginalized actors seem to contribute to the preservation of their peripheral position by considering the arguments of the dominating speakers as more valuable. Figure 5 illustrates such a situation in group 1.

\section{[FIGURE 5 ABOUT HERE]}

\section{Discussion and Implications}


The results as described in the previous section allow for optimistic as well as pessimistic considerations. At this point, however, we may only speculate on the reasons for the detected patterns of dominance.

Concerning inequalities in contribution, one may argue that, in terms of epistemic quality, the contributions of members of the less active groups may not have lived up to the contributions provided by the dominant speakers. Recognizing other actors to be the more eloquent advocates may have intimidated some actors from contribution and it might explain why the formers' views were more likely to find consideration. ${ }^{12}$ However, deliberative theory would meet such an approach to equal opportunities with reticence. A priori denying a particular social perspective or non-rational styles of communication from exerting political influence would be counterproductive to the goal of deliberative inclusion (e.g., Bohman, 2006; Cohen, 1989, p. 30). Furthermore, by enlarging the pool of admissible forms of deliberative communication such as rhetoric or storytelling, deliberative theory recently leveled the requirement for rational discourse, which gave pause to theorists calling for equal reasoning capacities (e.g., Bächtiger et al., 2010a; Dryzek, 2000).

Finding that consideration patterns are largely a reflection of the patterns for frequency of contribution recalls Sanders' (1997) meta-analysis of jury studies. Sanders (1997, p. 365) concludes that whether an argument prevails during deliberation is a matter of whether the argument has a 'talkative promoter'. A promising (though tentative) conclusion would be that by enhancing contribution equality, consideration biases could be attenuated. On the other hand, offering 'overspeaking' as a panacea to recognition may leave us with an uneasy feeling: a participant that only contributed once may offer a novel perspective or introduce critical remarks, while a participant that 'overspeaks' may add little to the discussion if he only repeats the same arguments several times. Nevertheless, if equal consideration automatically follows from equal contribution, purposive mechanisms of exclusion would be 
absent and all that would be needed is boosting the self-confidence of traditionally marginalized groups in order for them to participate at equal length.

From a practical point of view, however, one may question how participation equality could be enhanced further, given that DP already places so much emphasis on providing a favorable environment for free and equal participation. In DP, a crucial role is attributed to the neutral and well-trained facilitators that should be able to mitigate various kinds of inequalities (e.g., Fishkin and Luskin, 2005). To the extent that mini-public designs such as DP represent 'more perfect public spheres' (Fung, 2003, pg. 338), one may wonder whether detected inequalities such as the effect for working-class participants are more of a structural nature. In this regard, psychological literature would speak of a phenomenon called 'outgroup favoritism' where low-status groups favor high-status groups and thus add to a 'manifestation of the tendency to internalize and thus perpetuate the system of inequality' (Jost et al., 2004, p. 891).

Yet, a deliberative theory of facilitation has hitherto been missing (but see Moore, 2012), and facilitator intervention varied across Europolis group discussions (reference withheld). Whether and how facilitators manage to establish a fair and equal discussion atmosphere are important issues for future research. In this regard, future researchers should also pay more attention to group dynamics and social psychological mechanisms in order to contribute to a richer understanding of participation patterns in deliberative mini-publics.

\section{Conclusion}

In this article, I have proposed a pathway to evaluate equal participation during small group discussions in deliberative polling (DP). The main motivation for doing so is that informal impediments to participation may remain even after everyone is formally empowered to take part (e.g., Fraser, 1992; Sanders, 1997; Young, 2002). By accounting for the intrinsically relational aspect of interpersonal communication, the paper adds to the small but growing 
literature on deliberation that voices reservations about taking the willingness to engage with others claims for granted (e.g., Burkhalter, 2002; Dobson 2010, 2012; Stromer-Galley, 2007; Pedrini et al., 2013). Methodologically, the article responds to Mendelberg (2005) who argues for taking the deliberative context more seriously. As a consequence, multilevel modeling and social network analysis have been proposed as suitable tools of analysis.

In terms of contribution, the findings reveal that particularly women, members of new EUcountries and working-class participants spoke significantly and substantially less than their counterparts. Most importantly, results suggest a contextual effect on contribution: with increasing diversity of national backgrounds, women and new EU-members tend to give the floor to men and members of older EU-states. Yet the effects are more attenuated for the absolute amount of speaking time, while they are nuanced for the number of speeches made by individuals. When it comes to patterns of consideration, the article is far from concluding that the dominating groups purposely excluded the views of more peripheral actors. Rather, results suggest that the degree to which a speaker receives consideration from others largely depends on the number of speeches he or she contributes to the discussion. Thus, except for the working-class participants whose exclusion from the discussion is consistent and substantial, lacking consideration was not a serious issue for traditionally marginalized groups. Nevertheless and bearing in mind that DP is regarded as the 'gold standard' among existing mini-publics (Mansbridge, 2010), remaining inequalities and the highly contextual nature of small group participation give rise to some concerns and ask for further research on group dynamics and the role of facilitators in establishing a fair and equal discussion environment.

Of course, the article is limited in the scope and generalizability of its findings. First of all, the sample used in this study was small and results await confirmation from further research. Furthermore, the mere focus on equality during the deliberative process is strongly bound to 
the setting under examination. Recalling that the imperative in DP is learning and understanding rather than decision-making (Fung, 2003), a deliberative process has to make sure that the relevant reasons are aired and appropriately weighed in order for citizens to develop more informed and considered opinions (Mansbridge et al., 2012). In a setting where the aim is decision-making, one might also want to place emphasis on the nature of the deliberative outcome, for example in terms of inclusiveness, justice, or fairness (e.g., Rawls, 1971; Sanders, 1997). In the context of DP, future research may want to explore the relation between participation patterns and post-deliberative opinions. For example, finding that opinions were disproportionally influenced by the dominant participants would render even small discrepancies in deliberative participation more important.

Although this article was limited to the analysis of equality, content and quality of the contributions are also important criteria of successful participation in deliberative minipublics (e.g., Bächtiger et al., 2010b; Steiner et al., 2004). Future research will need to tell whether and to what extent these factors are linked to active participation in deliberative discussions. 


\section{Notes}

${ }^{1}$ But see Olsen and Trenz (2014) for a critical assessment of the representative status of a poll as part of a public constituency and as a generator of democratic legitimacy.

${ }^{2}$ As individual participants are embedded in small groups for discussion, multilevel modelling seems the appropriate approach (Mendelberg, 2005, pp. 641-642). Note that with $\mathrm{N}=13$, the number of the chosen subsample is rather small (but see Gelman and Hill, 2007, p. 247). Nevertheless, there is the danger that using maximum likelihood inference, variance components are not properly estimated and estimates and confidence intervals can be biased, particularly when cross-level interactions are estimated in models where the number of level-2 units is smaller than 15 (Stegmueller 2013). However, by assigning each individual to a particular group for discussion, the hierarchical structure in DP is straightforward, allowing for less complex models to be run. In order to estimate more complex models, fully Bayesian procedures would be appropriate (e.g., Hangartner et al., 2007). Where cross-level interactions are estimated, an informal approach to Bayesian inference complements the analyses: model simulations are run in order to retrieve an uncertainty distribution of the parameter estimates. The multilevel models run in this article are estimated using maximum likelihood estimation (MLE) with the lme4 package in R (Bates et al., 2011).

${ }^{3}$ Rater coder agreement RCA=0.79; Cohen's Kappa K=0.70; Spearman's $r=0.81$; Cronbach's alpha $\alpha=0.91$ $(\mathrm{N}=80)$.

${ }^{4}$ From a deliberative standpoint, however, receiving disrespectful feedback may be preferable to being completely ignored. I thank Michael Neblo for highlighting this point.

${ }^{5}$ One may argue that high centrality values could also just be the result of adherence to a particular argument or position as expressed by the following speakers. Thus, the fact that subsequent speakers refer to the first speech act may rather reflect convenience than power structures. However, given the nature of the mini-public design under scrutiny, these concerns can be countered to some extent. The fact that the general discussions in DP are fairly unstructured, participants get the possibility to state their views on a variety of problems, experiences, perspectives or policy solutions. In this sense, every participant has the chance to be the first in airing a particular aspect of the topic under discussion. Furthermore, the centrality measure of very active participants in Europolis is the sum of references received for various contributions.

${ }^{6}$ Furthermore, the sample of our Western European participants is rather homogeneous in that it does neither include participants from Ireland or Great Britain nor actual residents from the Nordic countries that are generally subsumed under different social welfare models (see Papadopoulus 2012), responses to regular and irregular migration (Düvell 2011) as well as attitudes toward immigration (Green 2007).

${ }^{7}$ See Appendix for exact variable description.

${ }^{8}$ Other factors such as conflict avoidance or psychological traits such as openness, extraversion or conscientiousness are said to be important antecedents of participation as well (e.g, Mondak and Halperin, 2008; Neblo et al., 2010). Yet the Europolis questionnaire did not include measures that encompass such psychological constructs. There are very few exceptions included in the questionnaire that could possibly tab single characteristics of such traits. However, including these variables would result in the loss of 13 valid observations, which is considerable given our small sample. Moreover, running the models including these variables does not produce substantive changes for our variables of interest and neither prove the effects of the psychological variables to be consistent. Point biserial correlations between the variables of interest and these psychological variables were rather low and never surpassed a value of 0.2 (results available on request).

${ }^{9}$ When it comes to age (older participants), attitudes towards immigration and belonging to Southern Europe, national heterogeneity did not prove to be an amplifying factor of inequalities. However, there is an almost significant interaction effect for working-class participants and the amount of speaking time as well as a significant effect for young participants and frequency of participation, but only when deliberating in extremely heterogeneous groups (results available on request).

${ }^{10}$ For the models, see Appendix, Table A.3. For more information on the group composition, see Appendix, Table A.1 and A.2. 


\footnotetext{
${ }^{11}$ However, this is only true for the variables of interest. Turning to controls, it becomes evident that although interest in politics is a strong driver of participation, it is not an explanatory factor for receiving consideration.

${ }^{12}$ However, we demonstrate elsewhere that the deliberative competence of women and members of new EUcountries that participated in Europolis does not significantly rank behind their dominating counterparts (reference withheld; see also Himmelroos, 2011). The results are different for working-class members: their contributions were of lower deliberative quality than those of higher class participants.
} 


\section{References}

Andersen, V. N. and Hansen, K. M. (2007) 'How Deliberation Makes Better Citizens: The Danish Deliberative Poll on the Euro', European Journal of Political Research, 46 (4), 531-556.

Bächtiger, A., et al. (2010a) 'Disentangling Diversity in Deliberative Democracy: Competing Theories, Their Blind Spots and Complementarities', Journal of Political Philosophy, 18 (1), 32-63.

Bächtiger, A., Pedrini, S. and Ryser, M. (2010b) 'Prozessanalyse politischer Entscheidungen: Deliberative Standards, Diskurstypen und Sequenzialisierung', in J. Behnke, T. Bräuninger, and S. Shikano (eds.), Jahrbuch für Handlungs- und Entscheidungstheorie. Wiesbaden: VS Verlag für Sozialwissenschaften, pp. 193-226.

Barabas, J. (2004) 'How Deliberation Affects Policy Opinions', American Political Science Review, 98 (4), 687-701.

Bates, D., Maechler, M. and Bolker, B. (2011) 'Linear Mixed-Effects Models Using S4 Classes', Available from: http://lme4.r-forge.r-project.org/ [Accessed 21 March 2012].

Benhabib, S. (1996) 'Toward a Deliberative Model of Democratic Legitimacy', in S. Benhabib (ed.), Democracy and Difference: Contesting the Boundaries of the Political. Cambridge: Cambridge University Press, pp. 67-94.

Benhabib, S. (2002) The Claims of Culture. Equality and Diversity in the Global Era. Princeton, University Press.

Bickford, S. (1996) The Dissonance of Democracy: Listening, Conflict, and Citizenship. New York: Cornell University Press.

Bohman, J. (1997) 'Deliberative Democracy and Effective Social Freedom: Capabilities, Resources, and Opportunities', in J. Bohman and W. Rehg (eds.), Deliberative Democracy: Essays on Reason and Politics. Cambridge, MA: The MIT Press, pp. 321-248.

Bohman, J. (2006) 'Deliberative Democracy and the Epistemic Benefits of Diversity', Episteme: A Journal of Social Epistemology, 3 (3), 175-191.

Bolker, B. (2010) Worked Analysis of Owl Data. Available from: http://glmm.wdfiles.com/local--files/examples/Owls.pdf. [Accessed 4 March 2013].

Borgatti, S. P. (2005) 'Centrality and Network Flow', Social Networks, 27 (1), 55-71.

Borgatti, S. P., Everett, M. and Freeman, L. (2002) Ucinet for Windows: Software for Social Network Analysis. Harvard: Analytic Technologies.

Burkhalter, S., Gastil, J. and Kelshaw, T. (2002) 'A Conceptual Definition and Theoretical Model of Public Deliberation in Small Face-to-Face Groups', Communication Theory, 12 (4), 398-422.

Childs, S. (2004) 'A Feminised Style of Politics? Women MPs in the House of Commons', The British Journal of Politics \& International Relations, 6 (1), 3-19.

Christiano, T. (2008) The Constitution of Equality: Democratic Authority and Its Limits: Democratic Authority and Its Limits. New York: Oxford University Press.

Cinalli, M. and O'Flynn, I. (2013) 'Public Deliberation, Network Analysis and the Political Integration of Muslims in Britain', The British Journal of Politics \& International Relations. Early View. 
Cohen, J (1989) 'Deliberation and Democratic Legitimacy', in A. Hamlin and P. Pettit (eds.), The Good Polity. Oxford: Blackwell, pp. 17-34.

Dobson, A. (2010) 'Democracy and Nature: Speaking and Listening', Political Studies, 58 (4), 752-768.

Dobson, A. (2012) 'Listening: The New Democratic Deficit', Political Studies, 60 (4), 843859.

Düvell, F (2011) 'Paths into Irregularity: The Legal and Political Construction of Irregular Migration', European Journal of Migration and Law, 13(3), 275-295.

Dryzek, J. S. (2000) Deliberative Democracy and Beyond: Liberals, Critics, Contestations. Oxford: Oxford University Press.

Estlund, D. (1997) 'Beyond Fairness and Deliberation: The Epistemic Dimension of Deliberative Authority', in J. Bohman and W. Rehg (eds.), Deliberative Democracy: Essays on Reason and Politics. Cambridge: MIT Press, pp. 127-160.

Estlund, D. (2000) 'Political Quality', Social Philosophy and Policy, 17 (1), 127-160.

Fearon, J. D. and Laitin, D. D. (2003) 'Ethnicity, Insurgency, and Civil War', American Political Science Review, 97 (1), 75-90.

Fishkin, J. S. (2009) When the People Speak: Deliberative Democracy and Public Consultation. Oxford: Oxford University Press.

Fishkin, J. S., et al. (2010) 'Deliberative Democracy in an Unlikely Place: Deliberative Polling in China', British Journal of Political Science, 40 (2), 435-448.

Fishkin, J. S. and Luskin, R. C. (2005) 'Experimenting with a Democratic Ideal: Deliberative Polling and Public Opinion', Acta Politica, 40 (3), 284-298.

Fraser, N. (1992) 'Rethinking the Public Sphere: A Contribution to the Critique of Actually Existing Democracy', in C. Calhoun (ed.), Habermas and the Public Sphere. Cambridge: MIT Press, pp. 109-142.

Fung, A. (2003) 'Survey Article: Recipes for Public Spheres: Eight Institutional Design Choices and Their Consequences', Journal of Political Philosophy, 11 (3), 338-367.

Geddes, A. (2003) The Politics of Migration and Immigration in Europe. London, SAGE.

Gelman, A. and Hill J. (2007) Data Analysis Using Regression And Multilevel/Hierarchical Models. New York: Cambridge University Press.

Goodin, R. E. (2000) 'Democratic Deliberation Within', Philosophy \& Public Affairs, 29 (1), 81-109.

Green, E. (2007) 'Guarding the gates of Europe: A typological analysis of immigration attitudes across 21 countries', International Journal of Psychology, 42(6), 365-379.

Gutmann, A. and Thompson, D. F. (1996) Democracy and Disagreement. Cambridge: Harvard University Press.

Hainmueller, J. and Hiscox, M. J. (2007) 'Educated Preferences: Explaining Attitudes Toward Immigration in Europe', International Organization, 61(02), 399-442.

Hangartner, D., et al. (2007) 'Mixing Habermas with Bayes: Methodological and Theoretical Advances in the Study of Deliberation', Swiss Political Science Review, 13 (4), 607644.

Hansen, K. M. (2004) Deliberative Democracy and Opinion Formation. Odense: University Press of Southern Denmark.

Hansen, K. M. (2010) 'The Equality Paradox of Deliberative Democracy: A Review of Theoretical Concepts and Empirical Findings', in M. R. Wolf, L. Morales L, and K. 
Ikeda (eds.), Political Discussions in Modern Democracies. New York: Routledge, pp. 26-43.

Himmelroos, S. (2011) 'Democratically Speaking: Can Citizen Deliberation Be Considered Fair and Equal?' Paper presented at the ECPR Joint Sessions, St. Gallen, 12-17 April.

Jost, J., Banaji, M., and Nosek, B. (2004) 'A Decade of System Justification Theory: Accumulated Evidence of Conscious and Unconscious Bolstering of the Status Quo', Political Psychology, 25(6), 881-919.

Karpowitz, C. F., Raphael, C. and Hammond, A. S. (2009) 'Deliberative Democracy and Inequality: Two Cheers for Enclave Deliberation among the Disempowered', Politics \& Society, 37 (4), 576-615.

Knight, J. and Johnson, J. (1997) 'What Sort of Political Equality Does Deliberative Democracy Require?' in J. Bohman and W. Rehg (eds.), Deliberative Democracy: Essays on Reason and Politics. Cambridge, MA: The MIT Press, pp. 279-319.

Krackhardt, D. (1990) 'Assessing the Political Landscape: Structure, Cognition, and Power in Organizations', Administrative Science Quarterly, 35 (2), 342-369.

Lazer, D., et al. (2010) 'The Coevolution of Networks and Political Attitudes', Political Communication, 27 (3), 248-274.

Lupia, A. (2002) 'Deliberation Disconnected: What it Takes to Improve Civic Competence', Law and Contemporary Problems, 65 (3), 133-150.

Luskin, R. C., Fishkin, J. S. and Jowell, R. (2002) 'Considered Opinions: Deliberative Polling in Britain', British Journal of Political Science, 32 (3), 455-487.

Luskin, R. C., et al. (2013) 'Deliberating across Deep Divides', Political Studies, Early View.

Mansbridge, J. (1983) Beyond Adversary Democracy. Chicago, IL, University of Chicago Press.

Mansbridge, J. (1999) 'Everyday Talk in the Deliberative System', in S. Macedo (ed.), Deliberative Politics: Essays on Democracy and Disagreement. New York: Oxford University Press, pp. 211-239.

Mansbridge, J. (2010) 'Deliberative Polling as the Gold Standard', The Good Society, 19(1), $55-62$.

Mansbridge, J., et al. (2012) 'A Systemic Approach to Deliberative Democracy', in J. Parkinson and J. Mansbridge (eds.), Deliberative Systems: Deliberative Democracy at the Large Scale. Cambridge: Cambridge University Press, pp. 1-26.

Masso, A. (2009) 'A Readiness to Accept Immigrants in Europe? Individual and CountryLevel Characteristics', Journal of Ethnic and Migration Studies, 35(2), 251-270.

McPherson, M., Smith-Lovin, L. and Cook, J. M. (2001) 'Birds of a Feather: Homophily in Social Networks', Annual Review of Sociology, 27 (1), 415-444.

Mendelberg, T. (2002) 'The Deliberative Citizen: Theory and Evidence', in M. X. Delli Carpini, L. Huddy, and R. Y. Shapiro (eds.), Political Decision Making, Deliberation and Participation: Research in Micropolitics, Volume 6. Greenwich, CT: JAI Press, pp. 151-193.

Mendelberg, T. (2005) 'Bringing the Group Back Into Political Psychology', Political Psychology, 26 (4), 637-650.

Mendelberg, T. and Oleske, J. (2000) 'Race and Public Deliberation', Political Communication, 17 (2), 169-191.

Moore, A. (2012) 'Following From the Front: Theorizing Deliberative Facilitation', Critical Policy Studies, 6 (2), 146-162. 
Mutz, D. C. (2006) Hearing the Other Side: Deliberative versus Participatory Democracy. Cambridge: Cambridge University Press.

Neblo, M. A., et al. (2010) 'Who Wants To Deliberate-And Why?' American Political Science Review, 104 (3), 566-583.

Norris, P. (1996) 'Women Politicians: Transforming Westminster?', Parliamentary Affairs, 49 (1), 89-102.

Olsen, E. and Trenz, H-J. (2013) 'From Citizens' Deliberation to Popular Will Formation? Generating Democratic Legitimacy in Transnational Deliberative Polling', Political Studies, 62(S1), 117-133.

Papadopoulos, T. (2011) 'Immigration and the variety of migrant integration regimes in the European Union', In: Carmel E, Cerami A, and Papadopoulos T (eds), Migration and Welfare in the New Europe: Social Protection and the Challenges of Integration, Bristol: Policy Press, pp. 23-46.

Pedrini, S., Bächtiger, A. and Steenbergen, M. R. (2013) 'Deliberative Inclusion of Minorities: Patterns of Reciprocity Among Linguistic Groups in Switzerland', European Political Science Review. Early View.

Price, V. (2009) 'Citizens Deliberating Online: Theory and Some Evidence', in T. Davies and S. P. Gangadharan (eds.), Online Deliberation: Design, Research, and Practice. Stanford: CSLI Publications, pp. 37-58.

Rawls, J. (1971) A Theory of Justice. Cambridge, MA: The Belknap Press.

Ryfe, D. M. (2006) 'Narrative and Deliberation in Small Group Forums', Journal of Applied Communication Research, 34 (1), 72-93.

Sanders, L. M. (1997) 'Against Deliberation', Political Theory, 25(3), 347-376.

Schneiderhan, E. and Khan, S. (2008) 'Reasons and Inclusion: The Foundation of Deliberation', Sociological Theory, 26 (1), 1-24.

Siu, A. (2009) 'Look Who's Talking: Examining Social Influence, Opinion Change and Argument Quality in Deliberation'. PhD thesis, Department of Communication Stanford University.

Smith, G. (2009) Democratic Innovations: Designing Institutions for Citizen ParticipationTheories of Institutional Design. New York: Cambridge University Press.

Stegmueller, D. (2013) 'How Many Countries for Multilevel Modeling? A Comparison of Frequentist and Bayesian Approaches', American Journal of Political Science. Early View.

Steiner, J., Bächtiger, A., Spörndli, M., et al. (2004) Deliberative Politics in Action. Cambridge: Cambridge University Press.

Stromer-Galley, J. (2007) 'Measuring Deliberation Content: A Coding Scheme. Journal of Public Deliberation, 3 (1), 1-35.

Thompson, D. F. (2008) 'Deliberative Democratic Theory and Empirical Political Science', Annual Review of Political Science, 11 (1), 497-520.

Trénel, M. (2009) 'Facilitation and Inclusive Deliberation', in T. Davies and S. P. Gangadharan (eds.), Online Deliberation: Design, Research, and Practice. Stanford University: Center for the Study of Language and Information/SRI, pp. 253-257.

Warren, M. E. (2001) Democracy and Association. Princeton: University Press.

Young, I. M. (2002) Inclusion and Democracy, paperback edition. Oxford: Oxford University Press. 
Tables and Figures

Table 1: Determinants of Contribution (incl. Silent Participants)

\begin{tabular}{|c|c|c|}
\hline & $\begin{array}{c}\text { Model } 1 \\
\text { Frequency }\end{array}$ & $\begin{array}{c}\text { Model } 2 \\
\text { Speaking Time }\end{array}$ \\
\hline \multicolumn{3}{|l|}{ Fixed effects } \\
\hline Intercept & $\begin{array}{l}1.563^{* * * *} \\
(0.166)\end{array}$ & $\begin{array}{l}5.621 * * * \\
(0.245)\end{array}$ \\
\hline Women & $\begin{array}{l}-0.111 \\
(0.116)\end{array}$ & $\begin{array}{l}-0.663 * * \\
(0.223)\end{array}$ \\
\hline Education & $\begin{array}{c}0.013 \\
(0.013)\end{array}$ & $\begin{array}{c}0.021 \\
(0.026)\end{array}$ \\
\hline Working-class & $\begin{array}{l}-0.261^{+} \\
(0.150)\end{array}$ & $\begin{array}{l}-0.312 \\
(0.280)\end{array}$ \\
\hline Younger participants & $\begin{array}{l}-0.144 \\
(0.152)\end{array}$ & $\begin{array}{c}0.018 \\
(0.292)\end{array}$ \\
\hline Older participants & $\begin{array}{l}-0.131 \\
(0.148)\end{array}$ & $\begin{array}{c}0.150 \\
(0.290)\end{array}$ \\
\hline Southern Europeans (SE) & $\begin{array}{l}-0.054 \\
(0.182)\end{array}$ & $\begin{array}{c}0.111 \\
(0.320)\end{array}$ \\
\hline Central Eastern Europeans (CEE) & $\begin{array}{l}-0.357^{+} \\
(0.188)\end{array}$ & $\begin{array}{l}-0.783 \\
(0.480)\end{array}$ \\
\hline Interest in politics & $\begin{array}{l}0.072^{*} \\
(0.030)\end{array}$ & $\begin{array}{l}0.184 * * * \\
(0.056)\end{array}$ \\
\hline Knowledge & $\begin{array}{l}0.038 \\
(0.063)\end{array}$ & $\begin{array}{c}0.301 * \\
(0.127)\end{array}$ \\
\hline Salience & $\begin{array}{l}-0.016 \\
(0.027)\end{array}$ & $\begin{array}{l}-0.003 \\
(0.053)\end{array}$ \\
\hline Attitudes (strongly progressive) & $\begin{array}{c}0.073 \\
(0.146)\end{array}$ & $\begin{array}{l}-0.239 \\
(0.289)\end{array}$ \\
\hline Attitudes (strongly conservative) & $\begin{array}{c}0.120 \\
(0.148)\end{array}$ & $\begin{array}{l}-0.447 \\
(0.281)\end{array}$ \\
\hline National heterogeneity of small group & $\begin{array}{l}-0.306 \\
(0.266)\end{array}$ & $\begin{array}{c}0.001 \\
(0.287)\end{array}$ \\
\hline \multicolumn{3}{|l|}{ Random effects } \\
\hline Individual level & $\begin{array}{c}0.244 \\
(0.494)\end{array}$ & $\begin{array}{c}1.942 \\
(1.394)\end{array}$ \\
\hline Group level & $\begin{array}{c}0.385 \\
(0.148) \\
\end{array}$ & $\begin{array}{c}0.770 \\
(0.877) \\
\end{array}$ \\
\hline AIC & 364.4 & 655.8 \\
\hline Log Likelihood & -166.2 & -311.9 \\
\hline
\end{tabular}

Notes: Multilevel models are estimated with the lme4 package in R (Bates et al., 2011). For contribution in speaking time, a linear hierarchical model with varying slopes for CEE participants is estimated. The dependent variable is operationalized as $\log$ of the total amount of speaking time. For frequency of contribution, a lognormal Poisson model is estimated (varying intercept) in order to account for overdispersion (Bolker, 2010; Bates et al., 2011). All ordinal and continuous predictor variables are centered at the mean. Estimated standard errors are shown in parentheses. ${ }^{+} \mathrm{p}<0.1,{ }^{*} \mathrm{p}<0.05,{ }^{* *} \mathrm{p}<0.01$., $* * * \mathrm{p}<.001$. Individual $\mathrm{N}=173$. Group $\mathrm{N}=13$. 
Table 2: Determinants of Contribution and Consideration (Active Speakers only)

\begin{tabular}{|c|c|c|c|}
\hline \multirow[b]{2}{*}{ Fixed effects } & \multicolumn{2}{|c|}{ Contribution } & \multirow{2}{*}{$\begin{array}{c}\text { Consideration } \\
\text { Model } 5 \text { Centrality }\end{array}$} \\
\hline & Model 3 Time & Model 4 Frequency & \\
\hline Intercept & $\begin{array}{l}5.527 * * * \\
(0.415)\end{array}$ & $\begin{array}{l}1.589 * * * \\
(0.160)\end{array}$ & $\begin{array}{l}0.962 * * * \\
(0.152)\end{array}$ \\
\hline Women & $\begin{array}{l}-0.343^{*} \\
(0.158)\end{array}$ & $\begin{array}{c}0.001 \\
(0.106)\end{array}$ & $\begin{array}{l}-0.145 \\
(0.133)\end{array}$ \\
\hline Education & $\begin{array}{c}0.008 \\
(0.018)\end{array}$ & $\begin{array}{c}0.013 \\
(0.011)\end{array}$ & $\begin{array}{c}0.012 \\
(0.014)\end{array}$ \\
\hline Working-class & $\begin{array}{l}-0.667 * * * \\
(0.196)\end{array}$ & $\begin{array}{l}-0.337^{*} \\
(0.136)\end{array}$ & $\begin{array}{l}-0.494 * * \\
(0.181)\end{array}$ \\
\hline Younger participants & $\begin{array}{l}-0.237 \\
(0.204)\end{array}$ & $\begin{array}{l}-0.242^{+} \\
(0.139)\end{array}$ & $\begin{array}{l}-0.150 \\
(0.174)\end{array}$ \\
\hline Older participants & $\begin{array}{l}-0.238 \\
(0.202)\end{array}$ & $\begin{array}{l}-0.232^{+} \\
(0.134)\end{array}$ & $\begin{array}{l}-0.298^{+} \\
(0.171)\end{array}$ \\
\hline Southern Europeans (SE) & $\begin{array}{c}0.119 \\
(0.220)\end{array}$ & $\begin{array}{l}-0.021 \\
(0.166)\end{array}$ & $\begin{array}{l}-0.307 \\
(0.203)\end{array}$ \\
\hline Central Eastern Europeans (CEE) & $\begin{array}{l}-0.209 \\
(0.270)\end{array}$ & $\begin{array}{l}-0.230 \\
(0.174)\end{array}$ & $\begin{array}{l}-0.185 \\
(0.201)\end{array}$ \\
\hline Interest in politics & $\begin{array}{l}0.108^{* *} \\
(0.039)\end{array}$ & $\begin{array}{l}0.052^{+} \\
(0.027)\end{array}$ & $\begin{array}{c}0.006 \\
(0.034)\end{array}$ \\
\hline Knowledge & $\begin{array}{c}0.110 \\
(0.088)\end{array}$ & $\begin{array}{l}-0.015 \\
(0.057)\end{array}$ & $\begin{array}{c}0.006 \\
(0.072)\end{array}$ \\
\hline Salience & $\begin{array}{l}-0.010 \\
(0.037)\end{array}$ & $\begin{array}{l}-0.014 \\
(0.024)\end{array}$ & $\begin{array}{l}-0.016 \\
(0.030)\end{array}$ \\
\hline Attitudes (strongly progressive) & $\begin{array}{l}-0.074 \\
(0.199)\end{array}$ & $\begin{array}{c}0.160 \\
(0.130)\end{array}$ & $\begin{array}{c}0.153 \\
(0.164)\end{array}$ \\
\hline Attitudes (strongly conservative) & $\begin{array}{l}-0.048 \\
(0.200)\end{array}$ & $\begin{array}{r}0.253^{+} \\
(0.135)\end{array}$ & $\begin{array}{l}0.390^{*} \\
(0.163)\end{array}$ \\
\hline National heterogeneity & $\begin{array}{c}0.065 \\
(0.193)\end{array}$ & $\begin{array}{l}-0.279 \\
(0.271)\end{array}$ & $\begin{array}{l}-0.219 \\
(0.207)\end{array}$ \\
\hline \multicolumn{4}{|l|}{ Random effects } \\
\hline Individual level & $\begin{array}{c}0.898 \\
(0.948)\end{array}$ & $\begin{array}{c}0.154 \\
(0.393)\end{array}$ & $\begin{array}{c}0.161 \\
(0.401)\end{array}$ \\
\hline Group level & $\begin{array}{c}0.133 \\
(0.365) \\
\end{array}$ & $\begin{array}{c}0.166 \\
(0.407) \\
\end{array}$ & $\begin{array}{c}0.047 \\
(0.217) \\
\end{array}$ \\
\hline AIC & 501.8 & 301.5 & 282.5 \\
\hline Log Likelihood & -234.9 & -134.8 & -125.2 \\
\hline
\end{tabular}

Notes: Multilevel models are estimated with the lme4 package in R (Bates et al. 2011). For contribution in speaking time, a linear hierarchical model with varying slopes for CEE participants is estimated. The dependent variable is operationalized as log of the total amount of speaking time. For frequency of contribution and consideration, lognormal Poisson models are estimated (varying intercept) in order to account for overdispersion (Bolker, 2010; Bates et al., 2011). All ordinal and continuous predictor variables are centered at the mean. Estimated standard errors are shown in parentheses. ${ }^{+} \mathrm{p}<0.1,{ }^{*} \mathrm{p}<0.05,{ }^{*} \mathrm{p}<00.01$, $* * * \mathrm{p}<.001$. Individual $\mathrm{N}=163$. Group $\mathrm{N}=13$. 
Figure 1: The Effect of Women and CEE Participants on Contribution by National

\section{Heterogeneity of Small Groups}
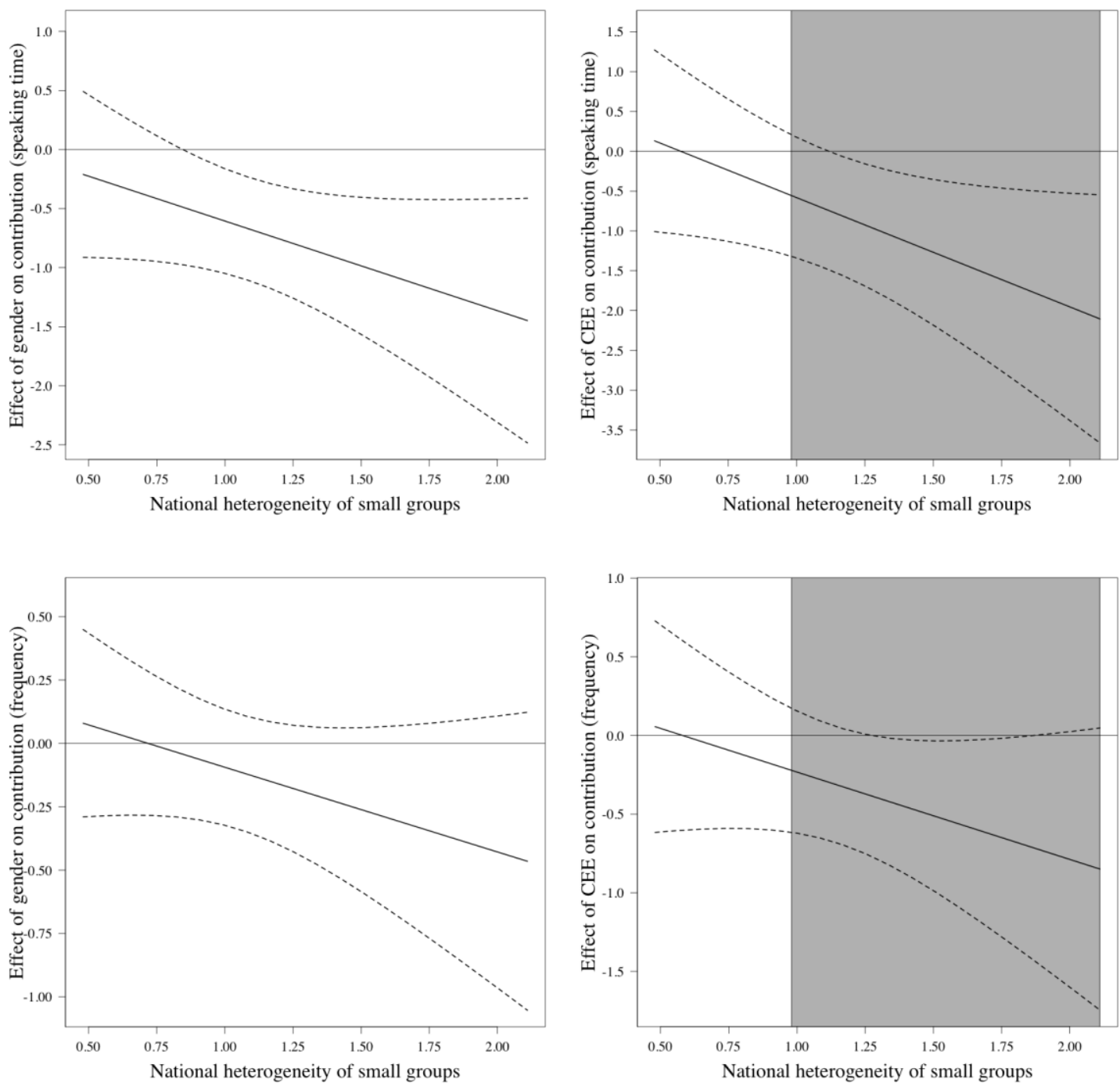

Note: Marginal effect and 95\% confidence intervals are based on the hierarchical models presented in Table S2-1 in the Appendix S2. The shaded areas demarcate the location of the groups in which CEE participants were engaging with participants from older EU-member states (WE, SE, or both). See also Figure S2-1 and Figure S2-2 (Appendix S2) for the results of the simulation of the conditional effects. 
Figure 2: The Effect of Women and CEE Participants on Consideration by National

\section{Heterogeneity of Small Groups}
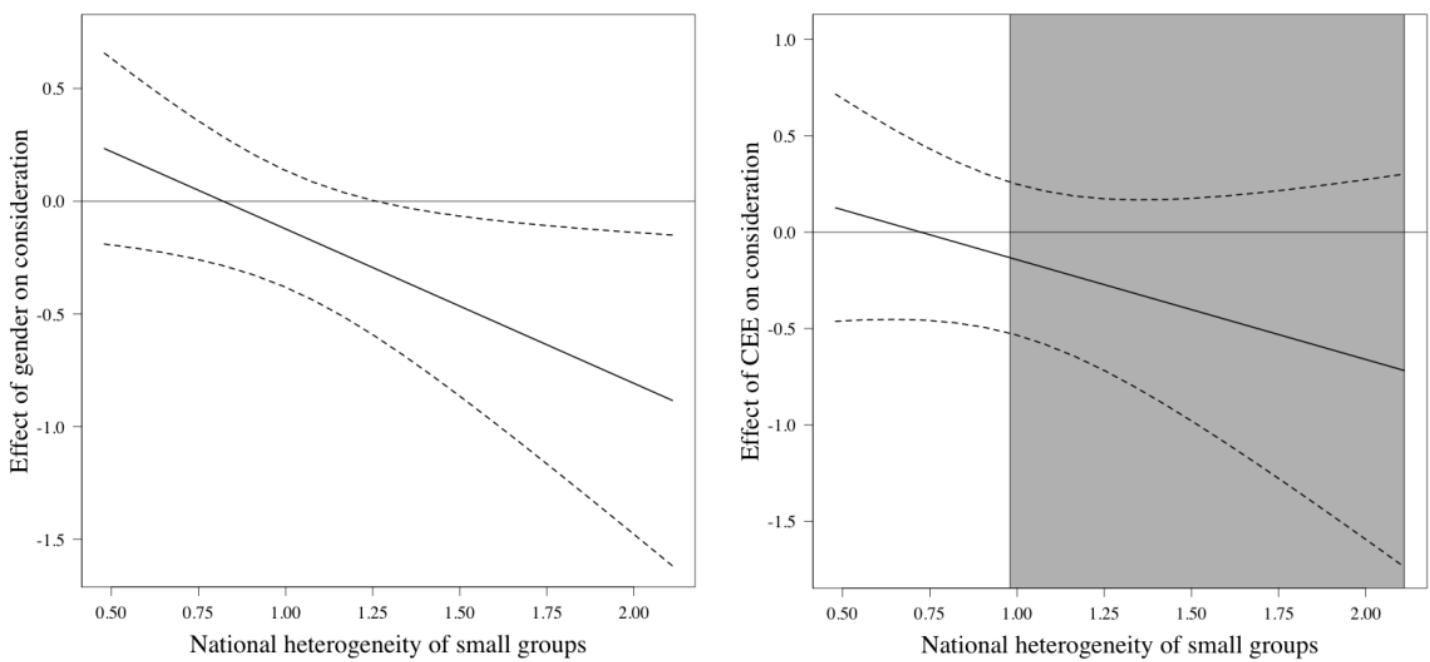

Note: Marginal effect and 95\% confidence intervals are based on the hierarchical models presented in Table S2-3 in the Appendix S2. The shaded areas demarcate the location of the groups in which CEE participants were engaging with participants from older EU-member states (WE, SE, or both). See also Figure S2-3 and S2-4 (Appendix) for the results on the simulation of the conditional effects. 
Figure 3: Homophily Effects for Members of the Dominant and Peripheral Groups

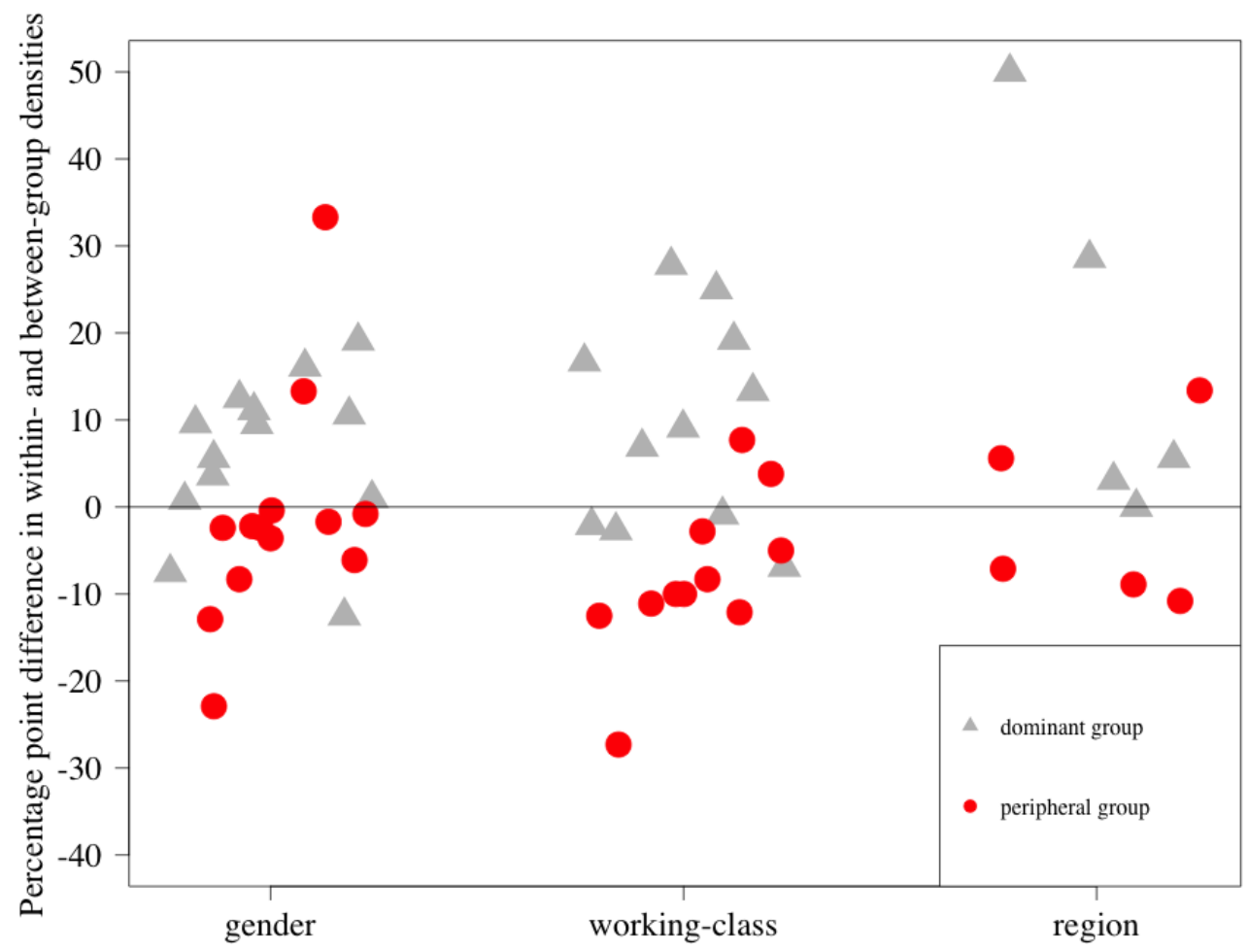

Note: For the corresponding entries to the Figure, see Appendix S3. 
Figure 4: Network of Consideration (Group 9)

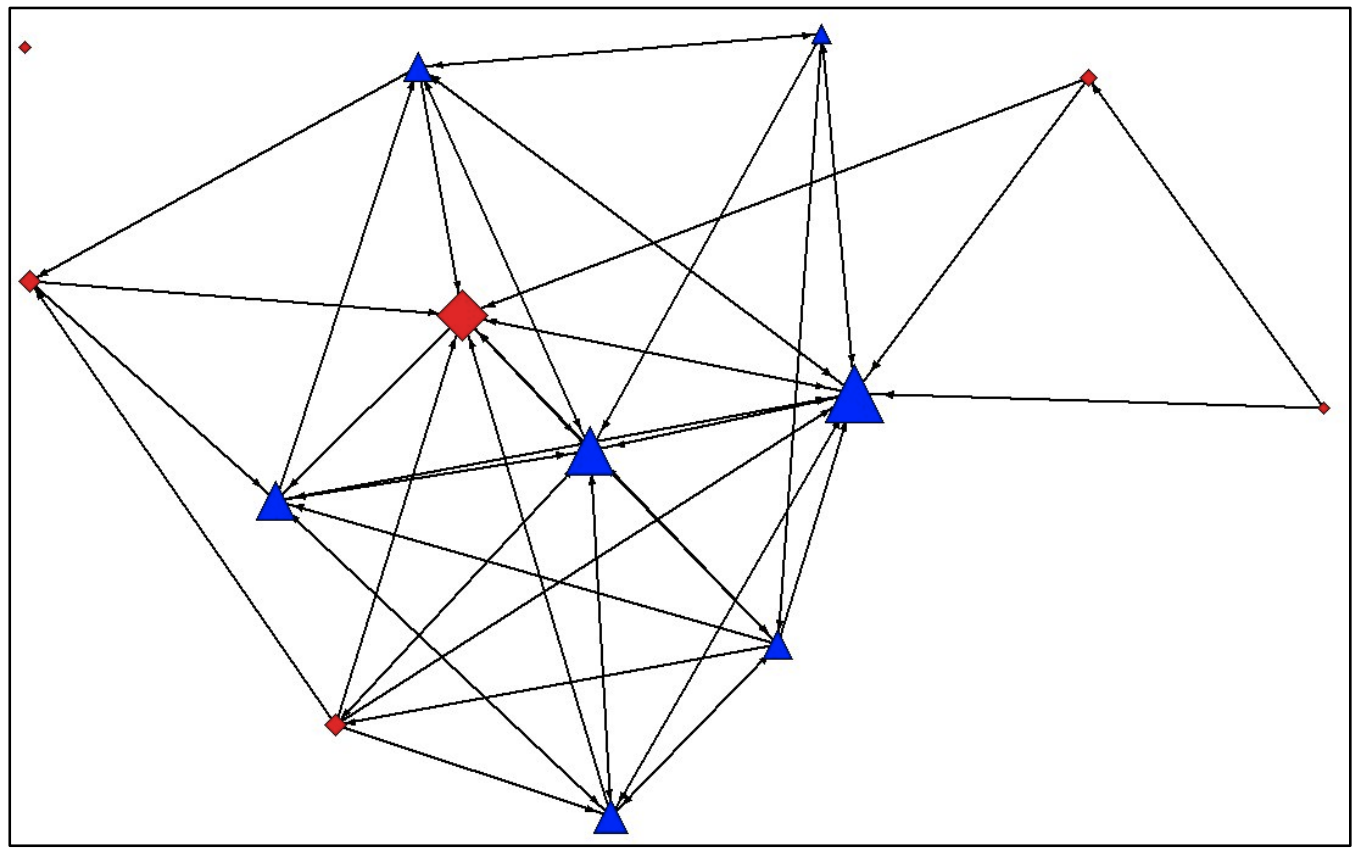

Note: Attributes display country affiliation. Diamonds are used for CEE participants (Polish), triangles for WE participants (Germans and Austrian)). The size of the nodes is given by the indegree centrality of an actor (amount of references received from co-discussants). The arrows indicate the direction of the reference. Isolates (top left corner) indicate participants that contributed to the discussion but neither made a civil reference to someone nor received one. Graphs were created using NetDraw (Borgatti et al., 2002). 
Figure 5: Network of Consideration (Group 1)

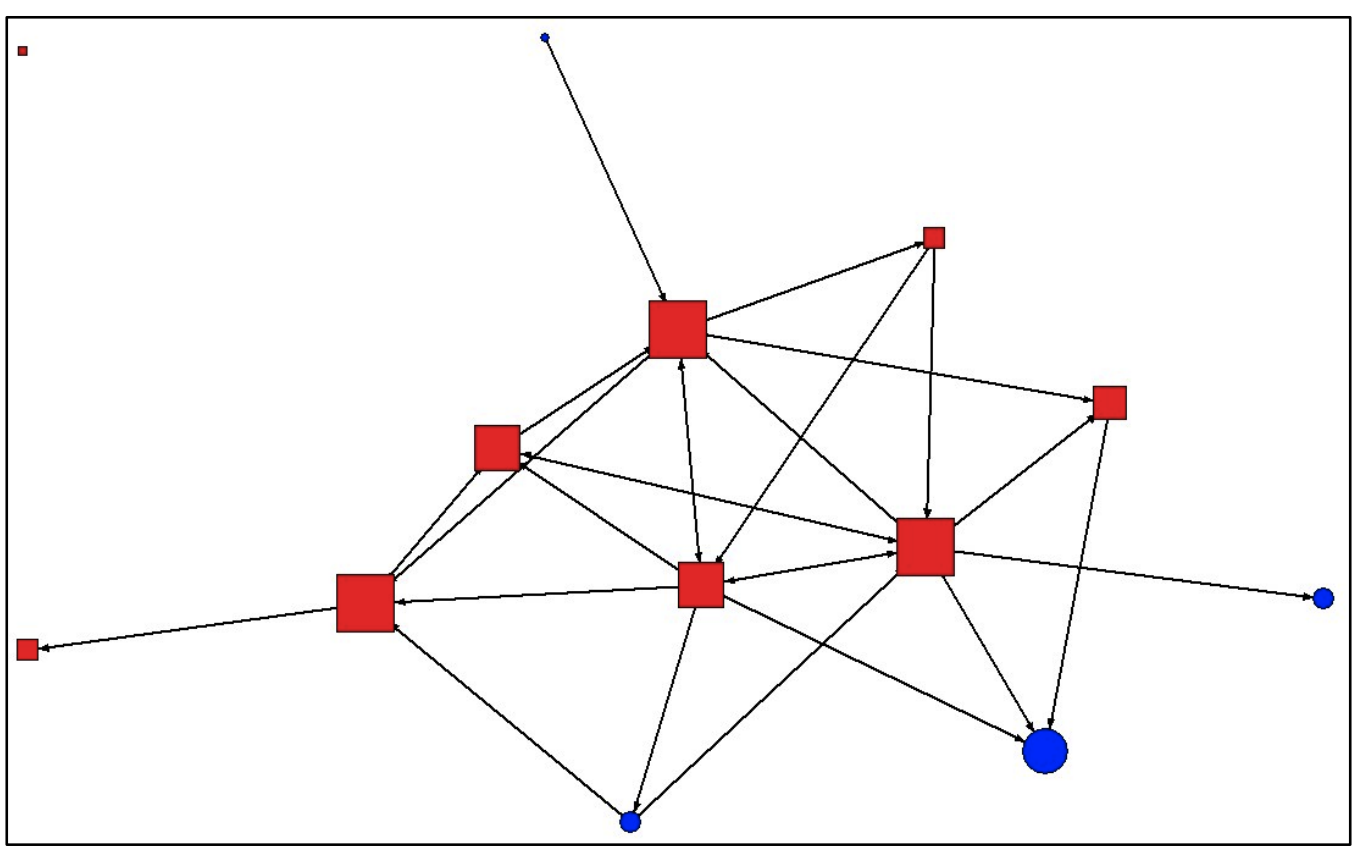

Note: Node attributes are shown for gender (men as squares, women as circles). The size of the nodes is given by the in-degree centrality of an actor (amount of references received from codiscussants). The arrows indicate the direction of the reference. Isolates (top left corner) indicate participants that contributed to the discussion but neither made a civil reference to someone nor received one. Graphs were created using NetDraw (Borgatti et al., 2002). 
Appendix S1

Descriptive statistics of selected sample 
Table S1-1: Group Composition of Selected Sample

\begin{tabular}{clcc}
\hline $\begin{array}{c}\text { Group } \\
\text { ID }\end{array}$ & Nationalities & heterogeneity $^{a}$ & $N$ \\
\hline 1 & 3 French, 6 Portuguese, 6 Romanians & 1.92 & 15 \\
2 & 8 French, 6 Hungarians & 0.98 & 14 \\
3 & 2 Belgians (Dutch speaking), 7 Dutch, 6 French & 0.62 & 15 \\
4 & 1 Austrian, 6 French, 7 Germans & 0.56 & 14 \\
9 & 1 Austrian, 6 Germans, 8 Polish & 1.10 & 15 \\
10 & 1 Belgian (French speaking), 6 French, 7 Spanish & 1.12 & 14 \\
16 & 9 Polish, 6 Slovenes & 0.48 & 15 \\
17 & 1 Austrian, 6 Germans, 8 Spanish & 1.10 & 15 \\
19 & 5 Danes, 4 Germans, 7 Spanish & 1.30 & 16 \\
20 & 1 Austrian, 5 Germans, 5 Lithuanians, 5 Spanish & 2.11 & 16 \\
21 & 1 Austrian, 7 French, 6 Germans, 1 Luxembourger & 0.61 & 15 \\
23 & 2 Belgians (Dutch speaking), 5 Dutch, 7 Polish & 1.20 & 14 \\
24 & 1 Austrian, 1 Cypriot, 8 Germans, 3 Greeks & 1.11 & 13 \\
\hline \hline
\end{tabular}

Note: ${ }^{\mathrm{a}}$ Index of national heterogeneity of small groups (see Table S1-2). 
Table S1-2: Variable Description and Comparison of Selected Sample to the Rest of the Groups

\begin{tabular}{|c|c|c|c|c|c|}
\hline & \multicolumn{2}{|c|}{$\begin{array}{c}\text { Selected Sample } \\
\quad(\mathrm{N}=191)\end{array}$} & \multicolumn{2}{|c|}{$\begin{array}{c}\text { Rest } \\
(\mathbf{N}=157)\end{array}$} & \multirow[b]{2}{*}{$t$-test } \\
\hline & $\begin{array}{l}\text { Mean } \\
(\text { Std. })\end{array}$ & $N$ & $\begin{array}{l}\text { Mean } \\
(\text { Std. })\end{array}$ & $N$ & \\
\hline $\begin{array}{l}\text { Women } \\
1=\text { female; } 0=\text { male }\end{array}$ & $\begin{array}{c}0.46 \\
(0.50)\end{array}$ & 191 & $\begin{array}{c}0.49 \\
(0.50)\end{array}$ & 157 & 0.55 \\
\hline $\begin{array}{l}\text { Age } \\
\text { Year of birth }\end{array}$ & $\begin{array}{l}1959.4 \\
(16.67)\end{array}$ & 191 & $\begin{array}{l}1961.9 \\
(16.63)\end{array}$ & 156 & 1.41 \\
\hline $\begin{array}{l}\text { Education } \\
\text { Age in year when main education ended }\end{array}$ & $\begin{array}{l}20.88 \\
(4.59)\end{array}$ & 171 & $\begin{array}{l}19.91 \\
(4.08)\end{array}$ & 133 & $-1.91^{+}$ \\
\hline $\begin{array}{l}\text { Working-class } \\
1=\mathrm{yes} ; 0=\text { no }\end{array}$ & $\begin{array}{c}0.22 \\
(0.41)\end{array}$ & 187 & $\begin{array}{c}0.26 \\
(0.44)\end{array}$ & 155 & 0.96 \\
\hline $\begin{array}{l}\text { Ideology } \\
\text { In political matters people talk of 'the left' and 'the right'. What is your position? Please } \\
\text { indicate your views using any number on a scale where ' } 0 \text { ' means 'left' and '10' means 'right'. }\end{array}$ & $\begin{array}{c}4.91 \\
(2.72)\end{array}$ & 184 & $\begin{array}{c}5.32 \\
(2.52)\end{array}$ & 146 & 1.42 \\
\hline $\begin{array}{l}\text { Salience } T 2 \\
\text { On a scale from } 0 \text { to } 10 \text {, where ' } 0 \text { ' is 'no problem at all', ' } 10 \text { ' is 'the most serious problem we } \\
\text { face', and ' } 5 \text { ' is 'exactly in the middle', how serious a problem or not would you say } \\
\text { immigration is? }\end{array}$ & $\begin{array}{c}5.72 \\
(2.40)\end{array}$ & 187 & $\begin{array}{c}6.61 \\
(2.47)\end{array}$ & 153 & $3.39^{* * *}$ \\
\hline $\begin{array}{l}\text { Knowledge T2 } \\
\text { Amount of correct answers to the three knowledge questions on immigration available in the } \\
\text { questionnaire. The questions asked for the definition of Blue Card workers, the role of the EU in } \\
\text { the current immigration policy and for a figure of the number of immigrants currently living in } \\
\text { the EU. For each of the questions, the participants could choose out of four possible options and } \\
\text { an additional 'don't know' category. }\end{array}$ & $\begin{array}{c}1.07 \\
(0.89)\end{array}$ & 191 & $\begin{array}{c}1.02 \\
(0.92)\end{array}$ & 157 & -0.56 \\
\hline $\begin{array}{l}\text { Interest in politics } T 2 \\
\text { On a scale from } 0 \text { to } 10 \text {, where ' } 0 \text { ' is 'not at all', ' } 10 \text { ' is 'passionately', and ' } 5 \text { ' is 'exactly in the } \\
\text { middle', how interested or not would you say you generally are in politics? }\end{array}$ & $\begin{array}{c}6.48 \\
(2.22)\end{array}$ & 188 & $\begin{array}{c}6.19 \\
(2.53)\end{array}$ & 155 & -1.11 \\
\hline
\end{tabular}


Attitude scale on immigration T2

This variable has been built as a scale from five central questions on immigration that proved to be substantially related in a test of inter-item correlation $(\alpha=0.76)$. The questions ask for participants' opinions on regularization/sending back irregular immigrants, reinforcing border controls, imposing penalties on employers who hire irregular immigrants, whether immigration increases criminality, and whether amnesty given to irregular immigrants will increase irregular immigration. The (standardised) scale has been generated automatically via the inter-item correlation command in Stata. The scale ranges from -1.27 to 2.17 with lower values indicating more conservative views on immigration.

National heterogeneity of small group

This measure is based on the Ethnolinguistic Fractionalisation Index (ELF) (Fearon and Laitin 2003). ELF $=1-\Sigma \mathrm{s}_{\mathrm{i}}{ }^{2}$ where $s_{i}$ is the share of group $i$ out of a total of $n$ groups (here: nationalities). The ELF scores have been weighed by a factor of 3 for groups that incorporated members from all three regions (WE, SE, and CEE), by a factor of 2 for groups that incorporated members from two out of the three regions, and by a factor of 1 when only one region was represented in the group. The group scores range from 0.48 to 2.11 , with higher values indicating more heterogeneous groups. The most homogeneous and the most heterogeneous groups are part of the selected sample.

Note: All variables (except 'national heterogeneity') are retrieved from the Europolis questionnaire dataset. T2 indicate questionnaire responses right at the start of the three-day event in Brussels, T3 indicate questionnaire responses right at the end of the three-day event. ${ }^{\text {a }}$ For the sake of interpretability, the poles of the original question have been exchanged in this paper. This is the reversed version of the question. T-test: ${ }^{+} \mathrm{p}<0.1,{ }^{*} \mathrm{p}<0.05,{ }^{* *} \mathrm{p}<0.01$, $* * * \mathrm{p}<0.001$. For a comparison between test- and control-group, visit http://ccd.stanford.edu. 
Appendix S2

Models with cross-level interactions (including simulated effects) 
Table S2-1: Determinants of Contribution (incl. Cross-Level Interaction)

\begin{tabular}{|c|c|c|c|c|}
\hline & \multicolumn{2}{|c|}{ Speaking Time } & \multicolumn{2}{|c|}{ Frequency } \\
\hline & Model A1 & Model A2 & Model A3 & Model A4 \\
\hline Intercept & $\begin{array}{l}5.596 * * * \\
(0.244)\end{array}$ & $\begin{array}{l}5.642 * * * \\
(0.251)\end{array}$ & $\begin{array}{l}1.550 * * * \\
(0.165)\end{array}$ & $\begin{array}{l}1.550 * * * \\
(0.160)\end{array}$ \\
\hline Women & $\begin{array}{l}-0.678 * * \\
(0.223)\end{array}$ & $\begin{array}{l}-0.657 * * \\
(0.225)\end{array}$ & $\begin{array}{l}-0.120 \\
(0.116)\end{array}$ & $\begin{array}{l}-0.114 \\
(0.117)\end{array}$ \\
\hline Education & $\begin{array}{c}0.019 \\
(0.026)\end{array}$ & $\begin{array}{c}0.026 \\
(0.026)\end{array}$ & $\begin{array}{c}0.012 \\
(0.013)\end{array}$ & $\begin{array}{c}0.015 \\
(0.013)\end{array}$ \\
\hline Working-class & $\begin{array}{l}-0.327 \\
(0.279)\end{array}$ & $\begin{array}{l}-0.289 \\
(0.284)\end{array}$ & $\begin{array}{l}-0.267^{+} \\
(0.149)\end{array}$ & $\begin{array}{l}-0.247 \\
(0.151)\end{array}$ \\
\hline Younger participants & $\begin{array}{c}0.044 \\
(0.291)\end{array}$ & $\begin{array}{l}-0.002 \\
(0.292)\end{array}$ & $\begin{array}{l}-0.134 \\
(0.151)\end{array}$ & $\begin{array}{l}-0.154 \\
(0.153)\end{array}$ \\
\hline Older participants & $\begin{array}{c}0.184 \\
(0.290)\end{array}$ & $\begin{array}{c}0.155 \\
(0.291)\end{array}$ & $\begin{array}{l}-0.118 \\
(0.148)\end{array}$ & $\begin{array}{l}-0.142 \\
(0.150)\end{array}$ \\
\hline Southern Europeans (SE) & $\begin{array}{c}0.109 \\
(0.319)\end{array}$ & $\begin{array}{c}0.041 \\
(0.362)\end{array}$ & $\begin{array}{l}-0.062 \\
(0.181)\end{array}$ & $\begin{array}{l}-0.090 \\
(0.226)\end{array}$ \\
\hline Central Eastern Europeans (CEE) & $\begin{array}{l}-0.724 \\
(0.450)\end{array}$ & $\begin{array}{l}-0.714^{+} \\
(0.379)\end{array}$ & $\begin{array}{l}-0.342^{+} \\
(0.187)\end{array}$ & $\begin{array}{l}-0.276 \\
(0.190)\end{array}$ \\
\hline Interest in politics & $\begin{array}{l}0.190^{* * * *} \\
(0.056)\end{array}$ & $\begin{array}{l}0.177 * * \\
(0.056)\end{array}$ & $\begin{array}{l}0.075^{*} \\
(0.030)\end{array}$ & $\begin{array}{l}0.070^{*} \\
(0.030)\end{array}$ \\
\hline Knowledge & $\begin{array}{l}0.294^{*} \\
(0.126)\end{array}$ & $\begin{array}{l}0.315^{*} \\
(0.126)\end{array}$ & $\begin{array}{c}0.039 \\
(0.063)\end{array}$ & $\begin{array}{c}0.040 \\
(0.064)\end{array}$ \\
\hline Salience & $\begin{array}{l}-0.003 \\
(0.053)\end{array}$ & $\begin{array}{c}0.002 \\
(0.054)\end{array}$ & $\begin{array}{l}-0.016 \\
(0.027)\end{array}$ & $\begin{array}{l}-0.015 \\
(0.027)\end{array}$ \\
\hline Attitudes (strongly progressive) & $\begin{array}{c}-0.202 \\
(0.288)\end{array}$ & $\begin{array}{l}-0.260 \\
(0.291)\end{array}$ & $\begin{array}{c}0.090 \\
(0.146)\end{array}$ & $\begin{array}{c}0.056 \\
(0.147)\end{array}$ \\
\hline Attitudes (strongly conservative) & $\begin{array}{l}-0.434 \\
(0.280)\end{array}$ & $\begin{array}{l}-0.441 \\
(0.285)\end{array}$ & $\begin{array}{c}0.136 \\
(0.148)\end{array}$ & $\begin{array}{c}0.122 \\
(0.152)\end{array}$ \\
\hline National heterogeneity of SG & $\begin{array}{c}0.329 \\
(0.356) \\
-0.759\end{array}$ & $\begin{array}{c}0.181 \\
(0.350)\end{array}$ & $\begin{array}{c}-0.163 \\
(0.284) \\
-0.334\end{array}$ & $\begin{array}{l}-0.138 \\
(0.289)\end{array}$ \\
\hline Heterogeneity $\mathrm{x}$ women & $(0.466)$ & & $(0.261)$ & \\
\hline Heterogeneity x CEE & & $\begin{array}{c}-1.372 * \\
(0.69) \\
-0.049\end{array}$ & & $\begin{array}{c}-0.555 \\
(0.432) \\
-0.062\end{array}$ \\
\hline Heterogeneity x SE & & $(0.728)$ & & $(0.467)$ \\
\hline Random effects & & & & \\
\hline Individual level & $\begin{array}{c}1.931 \\
(1.390)\end{array}$ & $\begin{array}{c}1.960 \\
(1.400)\end{array}$ & $\begin{array}{c}0.241 \\
(0.491)\end{array}$ & $\begin{array}{c}0.251 \\
(0.501)\end{array}$ \\
\hline Group level & $\begin{array}{c}0.610 \\
(0.781) \\
\end{array}$ & $\begin{array}{c}0.284 \\
(0.532) \\
\end{array}$ & $\begin{array}{c}0.144 \\
(0.380) \\
\end{array}$ & $\begin{array}{c}0.117 \\
(0.342) \\
\end{array}$ \\
\hline AIC & 654.9 & 654.2 & 364.8 & 366.8 \\
\hline Log Likelihood & -310.4 & -309.1 & -165.4 & -165.4 \\
\hline
\end{tabular}

Notes: Multilevel models are estimated with the lme4 package in R (Bates et al. 2011). For contribution in speaking time, a linear hierarchical model with varying slopes for CEE participants is estimated. The dependent variable is operationalised as log of the total amount of speaking time. For frequency of contribution, a lognormal Poisson model is estimated (varying intercept) in order to account for overdispersion (Bolker 2010; Bates et al. 2011). All ordinal and continuous predictor variables are centered at the mean. Estimated standard errors are shown in parentheses. ${ }^{+} \mathrm{p}<0.1$, $* \mathrm{p}<0.05, * * \mathrm{p}<0.01, * * * \mathrm{p}<.001$. Individual $\mathrm{N}=173$. Group $\mathrm{N}=13$. 
Table S2-2: Determinants of Consideration (incl. Cross-Level Interaction)

\begin{tabular}{|c|c|c|}
\hline & Model A5 & Model A6 \\
\hline Intercept & $\begin{array}{l}0.940 * * * \\
(0.153)\end{array}$ & $\begin{array}{c}0.937 * * * \\
(0.151)\end{array}$ \\
\hline Women & $\begin{array}{l}-0.172 \\
(0.133)\end{array}$ & $\begin{array}{l}-0.135 \\
(0.134)\end{array}$ \\
\hline Education & $\begin{array}{c}0.011 \\
(0.014)\end{array}$ & $\begin{array}{c}0.016 \\
(0.015)\end{array}$ \\
\hline Working-class & $\begin{array}{l}-0.505^{* *} \\
(0.179)\end{array}$ & $\begin{array}{l}-0.488^{* *} \\
(0.181)\end{array}$ \\
\hline Younger participants & $\begin{array}{l}-0.148 \\
(0.172)\end{array}$ & $\begin{array}{l}-0.144 \\
(0.175)\end{array}$ \\
\hline Older participants & $\begin{array}{l}-0.266 \\
(0.168)\end{array}$ & $\begin{array}{l}-0.304^{+} \\
(0.172)\end{array}$ \\
\hline Southern Europeans (SE) & $\begin{array}{l}-0.312 \\
(0.201)\end{array}$ & $\begin{array}{l}-0.469^{+} \\
(0.247)\end{array}$ \\
\hline Central Eastern Europeans (CEE) & $\begin{array}{l}-0.186 \\
(0.201)\end{array}$ & $\begin{array}{l}-0.180 \\
(0.202)\end{array}$ \\
\hline Interest in politics & $\begin{array}{c}0.014 \\
(0.034)\end{array}$ & $\begin{array}{c}0.001 \\
(0.035)\end{array}$ \\
\hline Knowledge & $\begin{array}{c}0.011 \\
(0.071)\end{array}$ & $\begin{array}{c}0.010 \\
(0.072)\end{array}$ \\
\hline Salience & $\begin{array}{l}-0.018 \\
(0.030)\end{array}$ & $\begin{array}{l}-0.014 \\
(0.031)\end{array}$ \\
\hline Attitudes (strongly progressive) & $\begin{array}{c}0.195 \\
(0.162)\end{array}$ & $\begin{array}{c}0.148 \\
(0.164)\end{array}$ \\
\hline Attitudes (strongly conservative) & $\begin{array}{l}0.432 * * \\
(0.161)\end{array}$ & $\begin{array}{l}0.434 * * \\
(0.168)\end{array}$ \\
\hline National heterogeneity of SG & $\begin{array}{c}0.026 \\
(0.240)\end{array}$ & $\begin{array}{l}-0.137 \\
(0.243)\end{array}$ \\
\hline Heterogeneity x women & $\begin{array}{l}-0.685^{*} \\
(0.320)\end{array}$ & \\
\hline Heterogeneity x CEE & & $\begin{array}{l}-0.518 \\
(0.432)\end{array}$ \\
\hline Heterogeneity x SE & & $\begin{array}{c}0.422 \\
(0.517)\end{array}$ \\
\hline Random effects & & \\
\hline Individual level & $\begin{array}{c}0.141 \\
(0.376)\end{array}$ & $\begin{array}{c}0.164 \\
(0.405)\end{array}$ \\
\hline Group level & $\begin{array}{c}0.056 \\
(0.237) \\
\end{array}$ & $\begin{array}{c}0.033 \\
(0.182) \\
\end{array}$ \\
\hline AIC & 279.8 & 283.8 \\
\hline Log Likelihood & -122.9 & -123.9 \\
\hline
\end{tabular}

Notes: Multilevel models are estimated with the lme4 package in R (Bates et al. 2011). Lognormal Poisson models are estimated (varying intercept) in order to account for overdispersion (Bolker 2010; Bates et al. 2011). All ordinal and continuous predictor variables are centered at the mean. Estimated standard errors are shown in parentheses. ${ }^{+} \mathrm{p}<0.1,{ }^{*} \mathrm{p}<0.05, * * \mathrm{p}<0.01, * * * \mathrm{p}<.001$. Individual $\mathrm{N}=163$. Group $\mathrm{N}=13$. 
Figure S2-1: Simulated Effect of Women on Contribution at Different Levels of National

\section{Heterogeneity}
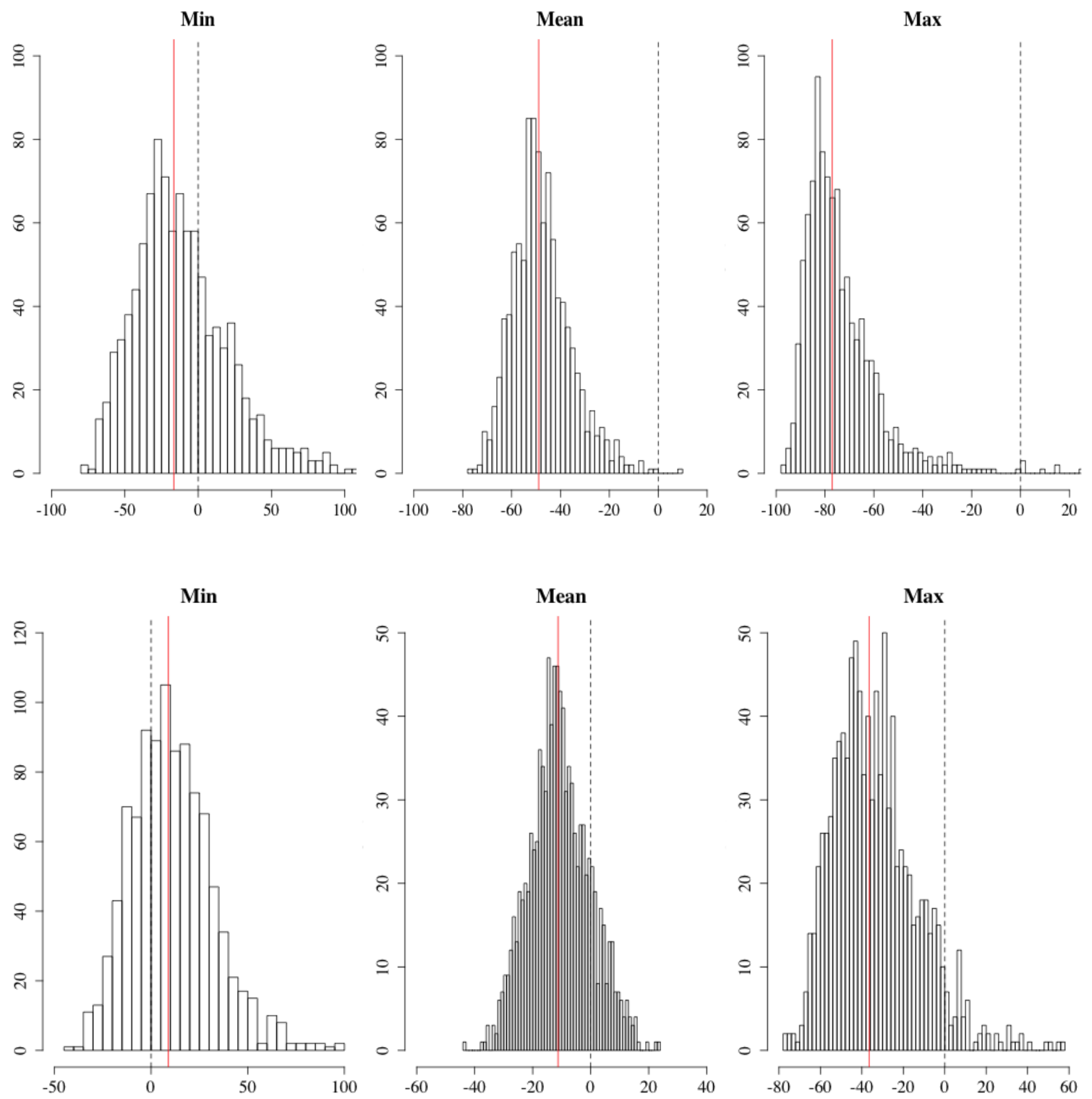

Note: Simulations are based on the statistical models presented in Table A3. The models were simulated in R (1000 draws). The first row shows the frequency distribution of the simulations for total amount of speaking time (Model A1), and the second row shows the distribution of the simulations for frequency of contribution (Model A3). The x-axis indicates the percentage difference in contribution that is attributed to the effect of being female, at the corresponding level of national heterogeneity and by holding all other factors constant. 
Figure S2-2: Simulated Effect of CEE Participants on Contribution at Different Levels

\section{of National Heterogeneity}
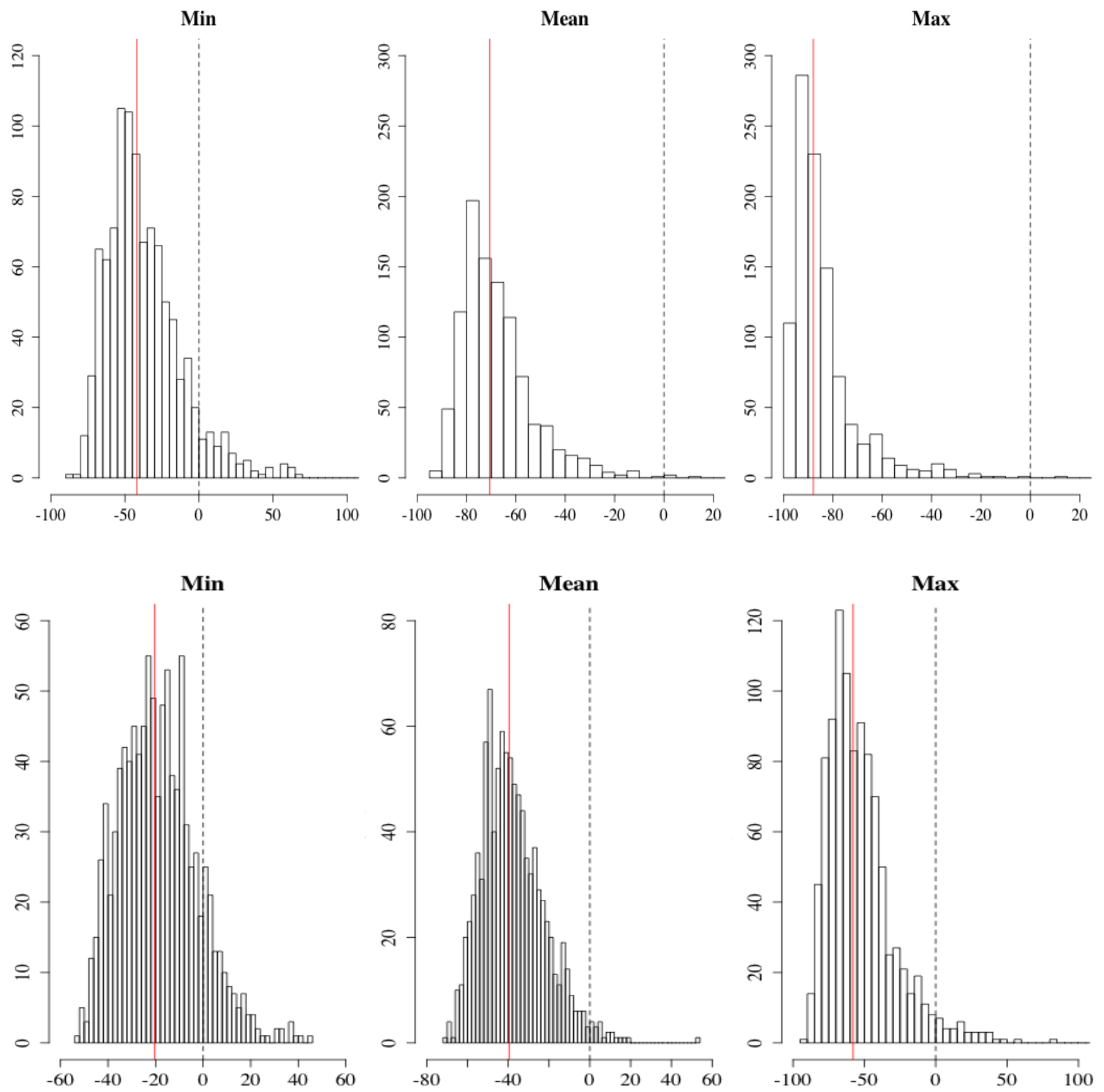

Note: Simulations are based on the statistical models presented in Table S2-1. The models were simulated in R (1000 draws). The first row shows the frequency distribution of the simulations for total amount of speaking time (Model A2), and the second row shows the distribution of the simulations for frequency of contribution (Model A4). The $\mathrm{x}$-axis indicates the percentage difference in contribution that is attributed to the effect of belonging to a CEE member state (compared to belonging to a WE member state), at the corresponding levels of national heterogeneity and by holding all other factors constant. Note that the minimum, mean and maximum value of national heterogeneity have been recalculated. Calculations solely base on the groups in which CEE participants were engaging with participants from WE and/or SE member states. 
Figure S2-3: Simulated Effect of Women on Consideration at Different Levels of

\section{National Heterogeneity}
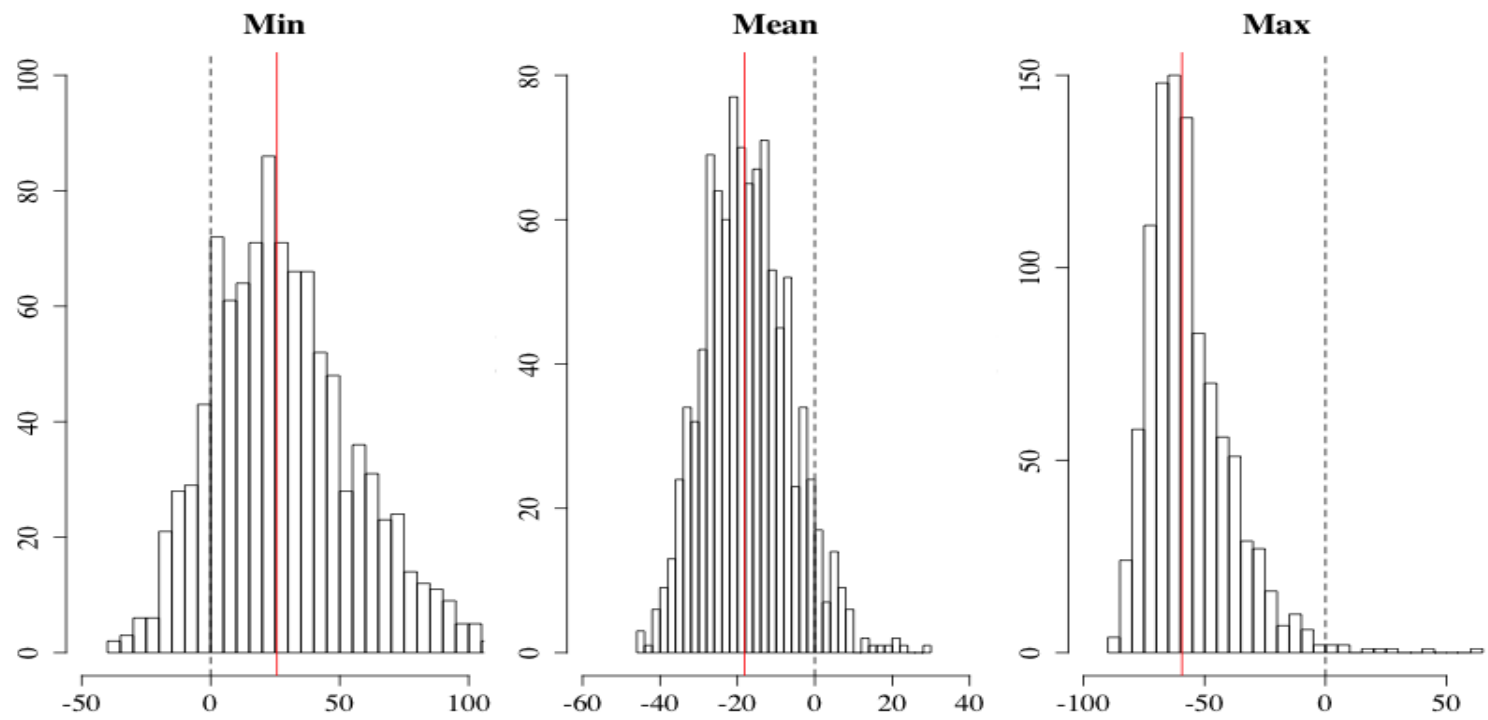

Note: Simulations are based on Model A5 presented in Table S2-2. The model was simulated in R (1000 draws). The $\mathrm{x}$-axis indicates the percentage difference in consideration that is attributed to the effect of being female, at the corresponding level of national heterogeneity and by holding all other factors constant.

Figure S2-4: Simulated Effect of CEE Participants on Consideration at Different Levels of National Heterogeneity
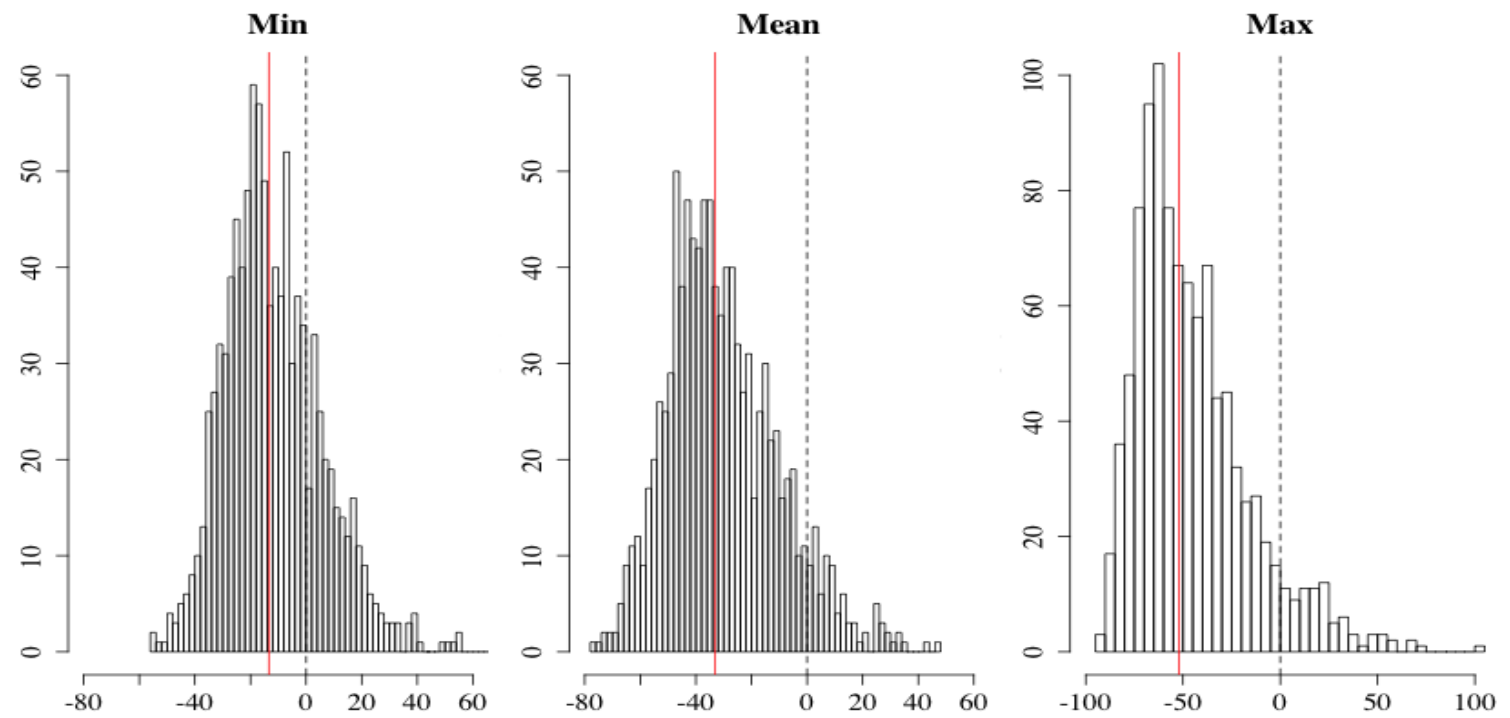

Note: Simulations are based on Model A6 presented in Table S2-2. The model was simulated in R (1000 draws). The $\mathrm{x}$-axis indicates the percentage difference in consideration that is attributed to the effect of belonging to a CEE member state (compared to belonging to a WE member state), at the corresponding levels of national heterogeneity of the group discussions and by holding all other factors constant. Note that the minimum, mean and maximum value of national heterogeneity have been recalculated: new calculations solely base on the groups in which CEE participants were engaging with participants from WE and/or SE member states. 
Appendix S3

Network densities per group 
Table S3-1: Network Densities of Consideration (Gender)

\begin{tabular}{ccccccc}
\hline $\begin{array}{c}\text { Group } \\
\text { ID }\end{array}$ & \multicolumn{2}{c}{$\begin{array}{c}\text { Within-group } \\
\text { references }\end{array}$} & \multicolumn{2}{c}{$\begin{array}{c}\text { Between-group } \\
\text { references }\end{array}$} & $\begin{array}{c}\text { Percentage point } \\
\text { difference between within- } \\
\text { and between-group }\end{array}$ \\
\hline & Men to Men & $\begin{array}{c}\text { Women to } \\
\text { Women }\end{array}$ & $\begin{array}{c}\text { Men to } \\
\text { Women }\end{array}$ & $\begin{array}{c}\text { Women to } \\
\text { Men }\end{array}$ & Men & Women \\
\cline { 2 - 7 } 1 & 0.264 & 0.000 & 0.139 & 0.083 & 12.5 & -8.3 \\
2 & 0.286 & 0.107 & 0.125 & 0.143 & 16.1 & -3.6 \\
3 & 0.125 & 0.200 & 0.200 & 0.067 & -7.5 & 13.3 \\
4 & 0.304 & 0.100 & 0.208 & 0.229 & 9.6 & -12.9 \\
9 & 0.429 & 0.200 & 0.238 & 0.429 & 19.1 & -22.9 \\
10 & 0.214 & 0.119 & 0.204 & 0.143 & 1.0 & -2.4 \\
16 & 0.181 & 0.583 & 0.306 & 0.250 & -12.5 & 33.3 \\
17 & 0.179 & 0.119 & 0.143 & 0.143 & 3.6 & -2.4 \\
19 & 0.167 & 0.119 & 0.159 & 0.127 & 0.8 & -0.8 \\
20 & 0.119 & 0.067 & 0.024 & 0.071 & 9.5 & -0.4 \\
21 & 0.300 & 0.139 & 0.244 & 0.200 & 5.6 & -6.1 \\
23 & 0.222 & 0.250 & 0.111 & 0.267 & 11.1 & -1.7 \\
24 & 0.300 & 0.200 & 0.194 & 0.222 & 10.6 & -2.2 \\
\hline \hline
\end{tabular}

Note: Entries are to be read as percentages. In group 21, for example, $30 \%$ of all possible references between men were made. In the same group, men referenced women in $24.4 \%$ of possible cases. This results in a slight tendency for homophily (5.6 percentage point difference). The last two columns are the entries of Figure 3.

Table S3-2: Network Densities of Consideration (Working-class)

\begin{tabular}{ccccccc}
\hline \hline $\begin{array}{c}\text { Group } \\
\text { ID }\end{array}$ & \multicolumn{2}{c}{$\begin{array}{c}\text { Within-group } \\
\text { references }\end{array}$} & \multicolumn{2}{c}{ Between-group references } & \multicolumn{2}{c}{$\begin{array}{c}\text { Percentage point } \\
\text { difference between within- } \\
\text { and between-group }\end{array}$} \\
\hline & $N W$ to $N W$ & W to $W$ & $N W$ to $W$ & $W$ to $N W$ & $N W$ & $W$ \\
\cline { 2 - 7 } 1 & 0.155 & 0.000 & 0.182 & 0.273 & -2.7 & -27.3 \\
2 & 0.220 & 0.000 & 0.028 & 0.083 & 19.2 & -8.3 \\
3 & 0.152 & 0.000 & 0.083 & 0.125 & 6.9 & -12.5 \\
4 & --- & --- & --- & --- & --- & --- \\
9 & 0.417 & 0.250 & 0.250 & 0.278 & 16.7 & -2.8 \\
10 & 0.173 & 0.000 & 0.242 & 0.121 & -6.9 & -12.1 \\
16 & 0.378 & 0.000 & 0.100 & 0.100 & 27.8 & -10 \\
17 & 0.189 & 0.000 & 0.056 & 0.111 & 13.3 & -11.1 \\
19 & 0.200 & 0.150 & 0.109 & 0.073 & 9.1 & 7.7 \\
20 & 0.054 & 0.050 & 0.075 & 0.100 & -2.1 & -5.0 \\
21 & --- & --- & --- & --- & --- & -- \\
23 & 0.179 & 0.267 & 0.188 & 0.229 & -0.9 & 3.8 \\
24 & 0.300 & 0.000 & 0.050 & 0.100 & 25.0 & -10 \\
\hline \hline
\end{tabular}

Note: See note in Table S3-1 for an example. $N W=$ Non working-class participants; $W=$ working-class participants. Due to the lack of working-class participants in group 4 (only one $W$ ) and group 21 (no $W$ ), no consideration densities were calculated for the respective small group discussions. The last two columns are the entries of Figure 3. 
Table S3-3: Network Densities of Consideration (New CEE Members)

\begin{tabular}{ccccccc}
\hline $\begin{array}{c}\text { Group } \\
\text { ID }\end{array}$ & \multicolumn{2}{c}{$\begin{array}{c}\text { Within-group } \\
\text { references }\end{array}$} & \multicolumn{2}{c}{ Between-group references } & \multicolumn{2}{c}{$\begin{array}{c}\text { Percentage point } \\
\text { difference between within- } \\
\text { and between-group }\end{array}$} \\
\hline & old to old & new to new & old to new & new to old & old & new \\
\cline { 2 - 7 } 1 & 0.167 & 0.250 & 0.136 & 0.194 & 3.1 & 5.6 \\
2 & 0.179 & 0.071 & 0.179 & 0.179 & 0.0 & -10.8 \\
9 & 0.690 & 0.167 & 0.190 & 0.238 & 50.0 & -7.1 \\
20 & 0.089 & 0.167 & 0.033 & 0.033 & 5.6 & 13.4 \\
23 & 0.429 & 0.095 & 0.143 & 0.184 & 28.6 & -8.9 \\
\hline \hline
\end{tabular}

Note: See note in Table S3-1 for an example. new=participants from a new CEE member state; old=participants from an older member state (SE and/or WE). The last two columns are the entries of Figure 3. 